NBER WORKING PAPER SERIES

WHY DO PUBLIC FIRMS ISSUE PRIVATE AND PUBLIC SECURITIES?

\author{
Armando Gomes \\ Gordon Phillips \\ Working Paper 11294 \\ http://www.nber.org/papers/w11294 \\ NATIONAL BUREAU OF ECONOMIC RESEARCH \\ 1050 Massachusetts Avenue \\ Cambridge, MA 02138
}

April 2005

We thank the financial support provided by the Rodney White Center for financial research. We also thank John Graham for data on marginal tax rates and Murillo Campello, Mark Chen, Gerry Hoberg, Craig MacKinlay, Matthew Spiegel, Catherine Schrand as well as from seminar participants at Arizona, Boston University, Cornell, George Washington, Harvard, Illinois, Tulane, Minnesota, Penn State, Rochester, Rutgers, UBC, UCLA, Utah, Texas-Austin, Washington University, Wharton, and the NYU Five Star Conference for helpful comments. We alone are responsible for the conclusions and analysis in this paper. The views expressed herein are those of the author(s) and do not necessarily reflect the views of the National Bureau of Economic Research.

(O2005 by Armando Gomes and Gordon Phillips. All rights reserved. Short sections of text, not to exceed two paragraphs, may be quoted without explicit permission provided that full credit, including $\odot$ notice, is given to the source. 
Why Do Public Firms Issue Private and Public Securities?

Armando Gomes and Gordon Phillips

NBER Working Paper No. 11294

April 2005

JEL No. G0, G2, G3

\begin{abstract}
$\underline{\text { ABSTRACT }}$
We examine a comprehensive set of private and public security issuance decisions by publicly traded companies. We study private and public issues of debt, convertibles and common equity securities a total of 6 different security-market choices. The market for public firms issuing private securities is large. Of the over 13,000 issues we examine, more than half are in the private market. We find that asymmetric information and moral hazard problems play a large role in the public versus private market choice and the security type choice. Our findings show that asymmetric information impacts security choice in a particular pattern: Conditional on issuing in the public market we find a pecking order of security issuance holds, firms with higher measures of asymmetric information are less likely to issue equity. We find a reversal of this pecking order in the private market, firms with higher measures of asymmetric information are more likely to issue equity and convertibles. Second, we find risk and investment opportunities are important in determining which security type a firm issues. Firms with high risk, low profitability and good investment opportunities are more likely to choose equity and convertibles and to issue privately. The results support models of security issuance where private securities give investors more incentives to produce information and monitor the firm.

Armando Gomes

University of Pennsylvania

The Wharton School

Finance Department

2300 Steinberg Hall-Dietrich Hall

Philadelphia, PA 19104

gomes@wharton.upenn.edu

Gordon Phillips

University of Maryland

Robert H. Smith School of Business

College Park, MD 20742

and NBER

gphillips@rhsmith.umd.edu
\end{abstract}




\section{Why Do Public Firms Issue Private and Public Securities?}

\section{Introduction}

This study is a comprehensive examination of why public firms issue different security types and why they issue these securities in private versus public security markets. We study both private and public issues of debt, convertibles and common equity - a total of 6 different security-market choices. Our comprehensive database allows us to assess the factors that impact both security type and market choice. Private security markets are of increasing importance for public firms. Of the over 13,000 issues by public firms we examine, more than half are in the private market, comprising issuances of equity, debt and convertible bonds and convertible preferred stock (henceforth convertibles). Among these issues, private equity and convertibles issued by public firms comprise 58 percent of the equity and convertibles issues.

We explore two major determinants of the market in which firms sell securities and the type of securities

that firms issue. First, the existence of asymmetric information may induce firms to sell securities to private parties who may more efficiently produce information, thus mitigating adverse selection problems. Second, firm risk and investment opportunities may influence which security a firm issues to mitigate agency problems.

While previous studies have examined the importance of asymmetric information and agency problems, our study examines these determinants using security issuance decisions of multiple types and in different markets, and uses novel proxies for these determinants. Our study links three different databases, a private equity and convertible database, a private debt database and the SDC new issue database, to Compustat and CRSP in order to examine issuance decisions. We also link these databases to IBES to use analyst earnings forecast data to construct measures of asymmetric information and use information on the quality of corporate governance from both existing and hand-collected sources from firms' charters and bylaws.

Our results on the major determinants of security type and public versus private security issuance are as follows:

\section{(1.) Asymmetric information:}

Our results show that measures of asymmetric information are major determinants of the decision to use the private versus public securities markets. We have several central results on the importance of asymmetric information. First, firms with the higher analyst earnings forecast error and dispersion (our 
measures of asymmetric information) are more likely to issue private securities and in particular, private equity and private convertibles. Second, our results for the specific type of security issued show that conditional upon issuing in the public market, firms with higher analyst forecast error and dispersion are less likely to issue public equity and are more likely to issue public debt. Third, we find that conditional upon issuing in the private market, private equity and convertibles are more likely to be issued by firms with high levels of asymmetric information. We call these results the pecking order of security issuance.

While we do not examine capital structure directly, our overall results on security issuance do not provide support for Myers and Majluf (1984) traditional pecking order theory of capital structure. Our results for security issuance conditional on issuing in the public markets do provide support for a pecking order of security issuance, with public equity being less likely to be issued by firms with high measures of asymmetric information. However, our study does not overall support a traditional pecking order as we find a reversal of the pecking order for private markets - with private convertibles and equity being the most likely to be issued by firms with high measures of asymmetric information. ${ }^{2}$ These results are broadly consistent with Fulghieri and Lukin (2001) who argue that incentives for information production by private investors are higher the more information-sensitive the securities being issued are, and predict private equity securities are more likely to be issued by firms with asymmetric information when private offerings are attractive. ${ }^{3}$

Our findings on the abnormal returns around equity issues in the private and public markets also support the view that these two markets are noticeably distinct. Similarly to other studies, abnormal returns are negative (positive) for public (private) equity issues. In addition, these returns are negatively (positively) related with the degree of information asymmetry for public (private) equity offerings. This evidence also indicates that public equity investors believe that private equity investors produce or obtain valuable information, and learning about private equity investments is more valuable when there is more uncertainty surrounding firm value.

Our results on the importance of asymmetric information to multiple security issuance decisions are in contrast to mixed evidence in previous studies. Previous studies examining debt and equity issuance

\footnotetext{
${ }^{2}$ Shyam-Sunder and Myers (1999) find support for the pecking order. Frank and Goyal (2003) and Leary and Roberts (2004b) do not, and document that many small firms issue equity frequently. Lemmon and Zender (2002) find support for the pecking order when adding a firm's debt capacity and desire for financial slack.

${ }^{3}$ Note the securities disclosure laws, including Regulation FD, exempt communications by the firm from the disclosure restrictions when those communications are to investors who " have expressly agreed to maintain the communication in confidence pursuant to a confidentiality agreement." An article by Houston and Laitin (2000) at the law firm Robins, Kaplan, Miller and Ciresi L.L.P., states: "As a result, companies should require confidentiality agreements prior to disseminating diligence materials or offering memoranda that contain material non-public information to securities market professionals or shareholders who are likely to trade on the information."
} 
decisions have used either a subset of these data - not including private convertibles or private equity or have identified security issuance through the statement of cash flows from Compustat. Of particular importance, the statement of cash flows from Compustat does not identify whether the equity or debt issuance was in the public or private market. ${ }^{4}$ Our findings extend the results of Hertzel and Smith (1993) and $\mathrm{Wu}$ (2003) who examine just equity issues and find support for measures of asymmetric information being important for private placements of equity.

Fama and French (2002) also recognize that the statement of cash flows does not identify the source of equity capital for the firm. They show that equity is issued in many different markets and that issues of equity to employees and in mergers are much greater than public issues of equity for most firms. ${ }^{5}$ They show that firms, including small firms, issue equity frequently and conclude that asymmetric information is not important to capital structure and that the traditional Myers' pecking order of capital structure does not hold. Our results are not inconsistent with Fama and French - who examine capital structure - as firms with different degrees of asymmetric information may still issue the same type of security but choose to issue in private versus public markets.

\section{(2.) Risk and Investment Opportunities:}

Our second set of findings shows that risk and investment opportunities and the associated potential agency problems between equityholders and debtholders are also important in determining the choice of market and security - debt, convertibles, or equity. Our results show that firms with higher risk and higher measures of investment opportunities are most likely to issue equity and convertibles. These results are consistent with Green (1984) and Brennan and Schwartz (1988) who argue that management of a company with straight debt outstanding will have an incentive to increase the risk of a firm - thus when there is doubt about the future policy of the company, convertibles can reduce investment inefficiencies. We also find that the likelihood of private bank debt versus public debt increase with increases in risk and investment opportunities. These findings are consistent with Blackwell and Kidwell (1988) and Diamond (1991), where private debt, concentrated with a few lenders, creates more incentives to produce costly information and monitor the firm than public bond owned by dispersed bondholders. Having fewer lenders also makes the debt easier to renegotiate.

\footnotetext{
${ }^{4}$ MacKie-Mason (1990) and Helwege and Liang (1996) add data on private debt to Compustat data and find no role of asymmetric information on security choice, although MacKie-Mason reports that asymmetric information impacts market choice. Hovakimian, Opler and Titman (2001), Korajczyk and Levy (2003), and Chang, Dasgupta and Hillary (2004) do find a role for asymmetric information (as well as trade-off variables) impacting public security issuance using Compustat data.

${ }^{5}$ Fama and French (2002) use changes in the number of shares and the average market price to identify equity issues. This method does not identify private versus public equity issues. Leary and Roberts (2004b) also use the Fama and French method to identify equity issues and also find the traditional pecking order theory of capital structure does not hold.
} 
Our results for private versus public issuance of debt are largely consistent with previous empirical evidence. For example, the private-public debt choice has been explored by Houston and James (1996), Krishnaswami et al. (1999), Cantillo and Wright (2000) and more recently by Denis and Mihov (2002). ${ }^{6}$ They largely agree that higher risk and investment opportunities leads the firm to choose private bank debt over public debt. However, by considering all the security-market choices rather than a more limited choice set allow us to draw some novel implications. In particular, we show empirically that firms shift from public to private debt for moderate levels of risk but for high levels of risk they shift toward private convertibles or equity.

We also examine the impact of other factors including market timing, corporate governance and taxes. With respect to market timing, we find that firms are more likely to issue public equity as opposed to private equity after their stocks have risen recently. This result is consistent with market timing of equity issues to the public market versus timing of equity issues in general after market runups. We find that corporate governance, while statistically significant, is economically not important to security issuance decisions. Firms with higher-quality corporate governance are more likely to undertake a private placement than a public offering, however this result is economically not very important. This result is perhaps not surprising given that theory provides conflicting implications for the relation between agency costs of equity and the use of disciplining devices such as debt or private placements to potential monitors. ${ }^{7}$

Our results also show strong support for taxes and profitability impacting security issuance. Consistent with the classic trade-off motivation for issuing securities, we find that profitability sharply increases, while financial distress decreases, the probability of issuing debt in the private markets. An increase in the marginal tax rate also increases the probability of issuing debt. These findings are consistent with security issuance being used to solve multiple problems that the firm faces.

Overall, we show that identifying where the security is sold, in particular for equity and convertibles, is important for the security choice decision. Our results show that the sensitivity of issuing equity versus issuing debt to asymmetric information is fundamentally different in private versus public markets. We show that asymmetric information, risk, investment opportunities, and taxes are all extremely important in impacting security issuance decisions in external markets.

\footnotetext{
${ }^{6}$ Faulkender and Petersen (2005) also illustrate the importance of a firm's source of capital for its financing decisions. They show that firms with access to the public debt markets have significantly more leverage.

${ }^{7}$ For example, Grossman and Hart (1982) argue that firms with incentive problems should use debt to mitigate those problems. A similar argument is made by Kahn and Winton (1998) for the use of private placements to stimulate monitoring. However, managers have discretion over issuance decisions and the use of those disciplining devices may be plagued by the same conflicts that it is trying to resolve (see Zwiebel (1996)).
} 
The paper proceeds as follows. In the next section, we discuss the theoretical and empirical literature in more detail and present a reduced form model for our empirical analysis. Section 3 describes the data. Section 4 presents the empirical results and discussion. Section 5 concludes.

\section{Theoretical Background and Framework for Security-Market Choice}

A substantial amount of theory has focused on the role of asymmetric information and agency problems as primary determinants of the choice of security and market. In this section we review the main predictions of these models and review the existing empirical evidence. From the theory we present testable hypotheses that we will examine. We then formulate a reduced form econometric model that enable us to test these hypotheses. More generally, the econometric model will allow us to estimate the implied sensitivity of the firms' security issuance choices to proxies for asymmetric information and moral hazard problems.

\section{A. Theoretical Background and Prior Empirical Evidence}

\section{A1. Asymmetric Information}

One large strand of the literature focuses on problems related to adverse selection due to ex-ante information asymmetries between managers and investors. The classic articles are Myers and Majluf (1984) and Myers (1984) who show that asymmetric information result in a pecking order for external finance - with less informationally sensitive securities such as debt being chosen first by firms with asymmetric information. Moreover, this adverse selection problem may result in underinvestment because undervalued firms may refrain to raise finance due to the dilution cost of selling underpriced securities. Several papers that followed study how security design may mitigate or solve the adverse selection problem. In particular, Brennan and Schwartz (1987), Brennan and Kraus (1987), and Stein (1992) demonstrate that convertible securities can be used to solve the adverse selection problem.

The second large strand of the literature focuses on the incentives of investors to become informed and produce information about firms. Private placements to one or few investors (as opposed to a public offering to several investors) is another mechanism that resolves the adverse selection problem. In the context of debt offerings, Boyd and Prescott (1986) and Diamond (1984) argue that intermediaries such as banks have a cost advantage in producing information because a public offering to dispersed investors leads to either duplication of effort or a free-rider problem. In the context of equity offerings, Chemmanur and Fulghieri (1999) and Maksimovic and Pichler (1999) model how asymmetric information affects the choice between going public and private placements. Chemmanur and Fulghieri (1999) show that firms 
with significant information asymmetry may prefer a private placement than going public, because private investors can produce additional costly information, thereby reducing the informational disadvantage, while such incentives are not present when shares are sold to dispersed investors. ${ }^{8}$

The benefits of private placements vis à vis public offerings are also likely to be increasing in the information-sensitiveness of the security being issued. Private investors' information production capabilities are likely to be more relevant for equity issues than debt issues, as private information learned during the due diligence process are likely to impact more the value of equity than debt. Therefore, we expect to see more switching from public equity to private equity than from public debt to private debt as asymmetry of information becomes more severe. Similar relationships should hold for the comparison between equity and convertibles and between convertibles and debt.

The interaction between the security and market choice and asymmetric information is explored in Fulghieri and Lukin (2001). They show that incentives for information production by investors depend on the degree of information sensitivity of the securities being issued. Issuance of more information-sensitive securities provides greater incentives for information production by investors, thus reducing the extent of information asymmetry and conveying a more positive signal to uniformed investors. Fulghieri and Lukin predict a reversal of the pecking order when the costs of producing private information are relatively low, with the likelihood of issuing equity relative to debt being positively related to the degree of information asymmetry. However, the classic pecking order still holds when the costs of producing private information are high, in which case the firm is more likely to make a public offering.

Overall, these theories suggest several testable predictions:

$A S Y$ 1: Conditional on the security type, private securities are more likely to be issued than their public counterparts when the potential for adverse selection problems are more severe. $A S Y$ 2: The likelihood of switching from public to private markets, conditional on a security type, is increasing on the information-sensitiveness of the security.

$A S Y$ 3: Conditional on a private offering the reverse of the typical pecking order should hold. Conditional on a public offering we expect the pecking order to hold. That is, the likelihood of issuing securities that are more information sensitive is increasing (equity being the most information-sensitive security) or decreasing with the degree of information asymmetry depend-

\footnotetext{
${ }^{8}$ The cost of private placements though is that public offerings allow for better diversification of risks and more liquidity. Private placements may also give private investors a costly information monopoly or too much bargaining power (Rajan (1992)).
} 
ing on whether the securities are placed privately or publicly, respectively.

Empirically, early studies that examine stock returns around offerings are consistent with theory predictions. Wruck (1989), Hertzel and Smith (1993), Allen and Phillips (2000), Chaplinsky and Haushalter (2003), and Brophy et. al (2004) find positive stock market returns around private placements of equity and convertibles. These results are in contrast to the negative returns around public offerings of securities found in Asquith and Mullins (1986), Masulis and Korwar (1986), and Mikkelson and Parch (1986).

The asymmetric information theories also have implications for the stock price market reaction around issues depending on the security-market choice. We add to the existing empirical results on abnormal returns by examining whether the predicted relations between information asymmetry and returns in each market hold.

$A S Y$ 4: The abnormal return around issues should be negatively (positively) related with the degree of information asymmetry for public (private) offerings of information sensitive securities such as equity.

Related to asymmetric information, we also examine the extent that firms issue securities in markets based on recent market performance or market timing. While the effect of market timing on long-run capital structure is controversial - Baker and Wurgler (2002) find a long-run effect on capital structure, while Leary and Roberts (2004a) and Kayhan and Titman (2004) present new evidence that shows that the market timing effect on capital structure is limited or only exists for a shorter period- the impact of market timing factors on security issuance has been more consistent. Stock market runup prior to equity issuance has been shown to be significantly positive by Asquith and Mullins (1986) and Korajczyk, Lucas and McDonald (1991) show that equity issues are clustered following earnings announcements and good stock market performance. Lucas and McDonald (1990) provide a model of time varying asymmetric information that can explain these findings.

We expand this previous literature to look at the effect of market timing on security issuance across private versus public markets. The hypothesis we investigate is simple. We examine whether firms are more likely to issue public equity after periods in which the overall stock market and also their own stock has risen.

\section{A2. Risk, Investment Opportunities and Agency Problems between Claimants}

The literature has emphasized two classical types of moral hazard problems between security holders: the asset substitution problem (Jensen and Meckling (1976)) and the debt overhang or underinvestment 
problem (Myers (1977)). These problems are more severe for firms with volatile cash flows and low profitability (riskier firms) because the chances of entering in financial distress are higher, and agency problems are particularly acute for firms in financial distress. Also, agency problems are stronger for firms with better investment opportunities (often proxied by Tobin's $q$ and research and development expenditures) due to the higher potential cost of passing up valuable investment opportunities and the greater flexibility to undertake excessively risky projects. Similar considerations explain why these problems are likely to be greater for smaller firms.

The simplest solution to these debt-holder and equity-holder incentive problems is to issue equity rather than debt. ${ }^{9}$ Moreover, Green (1984) and Brennan and Schwartz (1988) propose that convertibles can mitigate agency costs of debt. Convertibles provide incentives for managers not to undertake excessive risk because convertible-holders have a call option on firm value, and the value of convertibles are relatively insensitive to shifts in firm risk -so investment decisions are not as distorted as when the firm issue straight debt.

Private placement of debt is another solution to the problem (Blackwell and Kidwell (1988), Diamond (1991), and Ramakrishnan and Thakor (1984)). When debt is sold to a smaller number of private investors they have more incentives to produce costly information and monitor the firm than dispersed public bondholders. Moreover, private debt is advantageous when the firm enters in financial distress because public debt is governed by the Trust Indenture Act of 1939, which makes renegotiation of public debt contracts more difficult than private debt (see Gorton and Winton (2003) for a recent survey of the literature). Both considerations also apply to convertibles. Therefore, private convertibles are less exposed to incentive problems than public convertibles - however we have not seen any references to this possibility in the literature.

The testable implications of these theories are thus the following:

AG1: Equity and convertibles are more likely to be issued by firms that are riskier and have more investment opportunities, for both private and public markets.

AG2: Private placements of debt and convertibles are more likely than public placements of debt and convertibles respectively in riskier and high growth firms.

Agency problems between managers and shareholders can also create significant distortions. Several papers following Grossman and Hart (1982) have used an ex-ante value maximization perspective to solve

\footnotetext{
${ }^{9}$ However, equity issues have other costs, such as adverse selection costs and no interest tax shield benefit.
} 
for the optimal mix of debt and equity. These papers predict that debt should be used to mitigate incentive problems; debt increases efficiency because it prevents empire building managers from financing unprofitable projects. The threat of takeover or loss of control is an alternative (or substitute) mechanism to the use of debt in curbing managerial distortions. Indeed Jensen and Ruback (1983), and Shleifer and Vishny (1989) argue that agency problems among shareholders and managers are particularly severe when managers can resist hostile takeovers. Therefore, an implication of the literature following Grossman and Hart (1982) is that debt should be used even more as a disciplining device in firms with powerful antitakeover defenses. Another mechanism to deal with managerial excess considered in the literature (e.g., Shleifer and Vishny (1989) or Kahn and Winton (1998)) is monitoring by large shareholders. A private placement of a block of shares to an investor that naturally becomes a large shareholder is a direct way to improve monitoring and concentrate ownership.

Managers, however, have discretion over leverage decisions and the use of debt or monitoring itself may be plagued by conflicts. For example, managers may prefer less than the optimal amount of debt due to a desire to reduce firm risk to protect their underdiversified human capital (Fama (1985)) or their dislike of performance pressure associated with large interest payments (Jensen (1986)). Zwiebel (1996) focuses on takeover threats as a driving force for the use of debt, and partially entrenched managers trade-off empire building ambitions with the need to ensure sufficient efficiency to prevent control challenges (see also Novaes and Zingales (1995) and Stulz (1990)). The more antitakeover defenses the firm have the lower can the debt level be that discourage control challenges, so the debt level should be negatively related to antitakeover defenses. Similar considerations are likely also to impact the likelihood of using a monitor.

Empirically, Hertzel and Smith (1993) and Wu (2003) do not find evidence that private placements are motivated by monitoring. Recently, Barclay, Holderness and Sheehan (2003) examine long-run equity returns following private placements and find evidence consistent with the conclusion that discounts to private equity are compensation to private blockholders for passively allowing management to become more entrenched. Our interpretation of the current theory and evidence is that the predictions for security issuance are mixed depending on whether managers with poor current governance have discretion in choosing securities. We thus just include corporate governance provisions to examine whether these provisions impact security issuance.

Finally, incentives to use debt financing increase with a firm's marginal tax rate due to deductibility of interest expenses. So the incremental use debt (and convertibles) could be driven by tax motives. Graham (1996) provides evidence that high-tax-rate firms issue more debt than low-tax-rate firms. In our analysis 
we also include the Graham's marginal tax rate as a control variable to evaluate the importance of taxes relative to other key variables for firms financing decisions.

\section{B. Reduced Form Model of Security-Market Issuance}

We estimate several different econometric models of security-market issuance decisions. These models allow us to precisely test our the predictions from the theory formulated in section $2 \mathrm{~A}$ regarding the importance of asymmetric information and agency problems to issuance decisions.

Our reduced-form econometric model assumes that the firm wants to raise external funds $I$ to invest in a project with positive NPV. Let the NPV of a firm when issuing security $j$ be $V_{j}(x)$ net of direct and indirect issuance costs, where $x$ is a vector of exogenous, observable firm characteristics, and $j=e, c, d, E, C, D$ denotes, respectively, private equity, private convertibles, private debt, public equity, public convertibles, and public debt. The firm chooses the securities-market $J$ that maximizes firm value. We model the (unobserved) value function as a linear function of observed relevant firm characteristics plus a random noise. We will consider several different specifications, both multinomial logit and nested logit models, for the security issuance decision based on different assumptions about the random noise or error.

The multinomial logit model is one of the models we estimate. In this model the random errors for each choice are independent and identically distributed with the extreme value distribution. The multinomial logit model, while appealing due to its simplicity, turns out not to be a good model for security issue decisions. ${ }^{10}$ This model assumes that choices between any two alternatives are independent of the othersi.e. the independence of irrelevant alternatives (IIA) assumption. The IIA assumption says that if one of the alternatives is removed from the model, the other alternatives will have an identical proportionate increase in their probability of being chosen. It turns out that when we remove private convertibles from the model, private equity disproportionately gains in probability versus the other choices. Likewise when we remove private debt from the choice set, public debt disproportionately gains in probability.

Thus we also estimate more general nested logit models, which do not impose the IIA assumption. ${ }^{11}$ An additional advantage of the nested logit model is that the theory, most notably Fulghieri and Lukin, makes predictions about issuance decision that are conditional on the market chosen (see hypothesis $A S Y 3$ ); moreover other hypotheses such as $A S Y 1$ and $A S Y 2$ make predictions about issuance conditional on the

\footnotetext{
${ }^{10}$ We do present the results of the simultaneous choice multinomial model in an appendix available from the authors for comparison purposes. If one examines these results our conclusions are similar and the results actually stronger than the nested logit models.

${ }^{11}$ Another possibility is to use a multinomial probit model. We attempted to estimate this model, however it did not converge given multinomial probit models are computationally very intensive and become impractical when the number of choices is above three and there is a large number of observations.
} 
security chosen. We thus estimate two different nested logit models (in the appendix, we provide details on these models and explicit formulas for the probabilities of making each choice). Model 1: In this model the error terms have generalized extreme value distributions which allow for correlation between the public and private choice for each security, and is suitable for tests conditional on the security choice. The model assumes choices are uncorrelated across securities. Model 2: In this model the error terms, which also have generalized extreme value distributions, allow for correlations within choices in the same market. The model assumes that choices are uncorrelated across markets, and it is suitable for tests conditional on the market choice. The model assumes choices are uncorrelated across securities.

All three models are estimated using the maximum likelihood estimation method. Given that models 1 and 2 are not nested within each other, there is no formal test of the appropriateness of one versus the other, but the multinomial logit model arises as a particular case of the nested logit models (when all errors are uncorrelated).

Model 1: The security-market nested logit model. This model corresponds intuitively to a situation in which firms pick the security they wish (debt, convertibles, or equity) to sell first and then choose the market, (public or private), in which they sell the security. Note that there are actually no explicit timing assumption built into this nested logit model, rather the choice between public and private is assumed to be correlated and the nested logit models this correlation. The value of each choice is given in the following table:

$$
\begin{aligned}
& \text { Choice } 1
\end{aligned}
$$

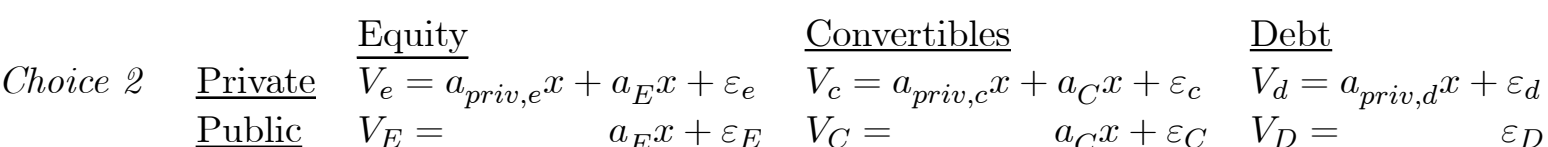

In the above table $a_{E} x$ and $a_{C} x$ are the values of choosing equity, $E$, and convertibles, $C$, respectively for a given characteristic $x$ (debt is normalized to zero), and $a_{p r i v, j} x$ is the additional value from the private choice for security choice $j$ indexed by $j=e, c, d$, respectively, equity, convertibles and debt.

A key property of model 1 is that the odds ratio between private and public choices can be explicitly determined. Thus the odds ratio between say private equity and public equity, conditional on the firm issuing equity, can be explicitly given by:

$$
\frac{P_{e}}{P_{E}}=\frac{\operatorname{Pr}[Y=e \mid \text { equity }]}{\operatorname{Pr}[Y=D \mid \text { equity }]}=e^{a_{p r i v, e} x}
$$

Therefore, the coefficient $e^{a_{p r i v, e}^{k}}$ describes the change in the odds ratio associated with an increase in $x_{k}$ (i.e., $\left.\frac{d\left(\frac{P_{e}}{P_{E}}\right)}{d x_{k}}=e^{a_{p r i v, e}^{k}}\right)$. Thus, if the coefficient $a_{p r i v, e}^{k}$ is positive (negative) then increases in the control 
variable $x_{k}$ increases (decreases) the relative odds of issuing private equity over public equity conditional on the firm issuing equity. Certainly, similar relationships apply to convertibles and debt, allowing us to test the various hypothesis discussed in the previous section about the relevance of the market choice conditional on the security choice. ${ }^{12}$

Model 2: The market-security nested logit model. This model corresponds intuitively to a situation in which firms first choose the market they wish to issue and then choose the type of security. Note that there are actually no explicit timing assumption built into this nested logit model, rather the choice between security type is assumed to be correlated and the nested logit models this correlation. The value of each choice is given by:

Choice 1

$\underline{\text { Private }} \quad \underline{\text { Public }}$

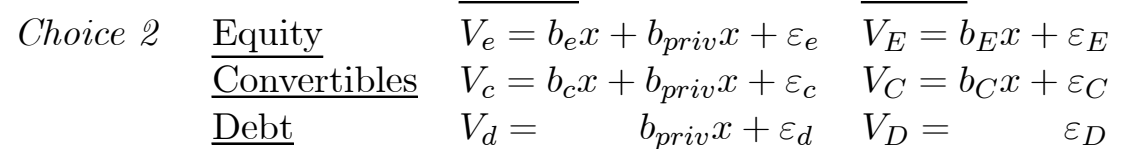

In the above table $b_{j} x$ is the additional value from choosing a particular security $j=e, c, E, C$ relative to debt, with $b_{\text {priv }} x$ the additional value a firm gets from making a decision to issue in the private markets.

A key property of model 2 is that the odds ratio between say public equity and public debt, conditional on the firm issuing publicly is explicitly given by

$$
\frac{P_{E}}{P_{D}}=\frac{\operatorname{Pr}[Y=E \mid p u b l i c]}{\operatorname{Pr}[Y=D \mid p u b l i c]}=e^{b_{E} x} .
$$

The coefficient $e^{b_{E}^{k}}$ is the odds ratio associated with an increase in $x_{k}$ (i.e., $\frac{d\left(\frac{P_{E}}{P_{D}}\right)}{d x_{k}}=e^{b_{E}^{k}}$ ). So, if the coefficient $e^{b_{E}^{k}}$ is positive (negative) then increases in the control variable $x_{k}$ increases (decreases) the relative odds of issuing public equity over public debt conditional on the firm issuing publicly. Note that we can also compare the relative odds of issuing public equity over public convertibles, conditional on issuing publicly (i.e., $\left.\frac{d\left(\frac{P_{E}}{P_{C}}\right)}{d x_{k}}=e^{\left(b_{E}^{k}-b_{C}^{k}\right)}\right)$. Other analogous relationships hold for the relative odds of issuing different securities in the private markets.

\section{Testing our hypotheses:}

Using the coefficients of the nested logit models we can test the following hypotheses related to the specific theories and predictions discussed in section 2.A.

\footnotetext{
${ }^{12}$ Note that the odds ratio among choices in different nests, say $\frac{P_{e}}{P_{c}}$, under the nested logit model 1 is a complicated function of all the alternatives (see appendix).
} 
Sensitivity to asymmetric information: Let $x_{k}$ represent the degree of asymmetric information facing the firm, and let $a_{p r i v, j}^{k}$ and $b_{j}^{k}$ be the coefficients with respect to variable $k$. We can test the following hypotheses about the importance of asymmetric information:

Hypothesis ASY1: $a_{p r i v, e}^{k}>0, a_{p r i v, c}^{k}>0, a_{p r i v, d}^{k}>0$. This hypothesis says that firms are more likely to issue private securities over public securities, conditional on a given security choice.

Hypothesis ASY2: $a_{\text {priv }, e}^{k}>a_{\text {priv }, c}^{k}>a_{\text {priv,d}}^{k}$. This ordering states that firms are more likely to issue private equity versus public equity than they are to issue private versus public convertibles, and private versus public debt, as the level of information asymmetry increases. ${ }^{13}$

Hypothesis ASY3: $b_{E}^{k}<b_{C}^{k}<0$, for public markets and $b_{e}^{k}>b_{c}^{k}>0$, for private markets. That is, the pecking order holds in public markets and the reverse of the pecking order holds in private markets.

Sensitivity to risk and agency problems: Let $x_{r}$ represent the risk and investment opportunity variables, and let $b_{j}^{r}$ and $a_{p r i v, d}^{r}$ be the coefficients with respect to variable $r$. We can test the following hypotheses about the importance of agency costs:

Hypothesis AG1: $b_{E}^{r}>b_{C}^{r}>0$, for public markets and $b_{e}^{r}>b_{c}^{r}>0$, for private markets. If agency cost of debt is important for firms we expect firms with higher risk and investment opportunities will choose equity over convertibles, and convertibles over debt.

Hypothesis AG2: $\quad a_{p r i v, d}^{r}>0$ and $a_{p r i v, c}^{r}>0$. This hypothesis says that firms that are riskier or have more investment opportunities are more likely to issue private debt (convertibles) over public debt (convertibles).

We do not explicitly state the hypotheses developed for corporate governance and agency problems as they depend on whether value maximization or managerial discretion are the predominant force in security issuance. Which motive dominates will depend on the signs of the estimated coefficients on the corporate governance variable. Moreover, tests of the effect of market timing and taxes can also be inferred from the estimated coefficients on those variables.

\section{Data}

\section{A. Data}

We study security issuance by public U.S. corporations from January 1995 to December 2003. The data on securities issuance comes from three different databases: PlacementTracker Database of Sagient

\footnotetext{
${ }^{13}$ Specifically, hypothesis $A S Y 2$ is equivalent to $\frac{d\left(\frac{P_{e}}{P_{E}}\right)}{d x_{k}}>\frac{d\left(\frac{P_{c}}{P_{C}}\right)}{d x_{k}}>\frac{d\left(\frac{P_{d}}{P_{D}}\right)}{d x_{k}}$.
} 
Research Systems, SDC new issues database, and DealScan database of the Loan Pricing Corporation.

The data source for privately placed common stock (or private equity deals) and privately placed convertibles preferred stock and bonds (henceforth, convertibles) is the PlacementTracker database of Sagient Research Systems. The company specializes in collecting data on private placements of common stock and convertibles primarily from SEC filings such as 8-Ks, 13Ds, 10-Ks and 10-Qs (coverage started in 1995, hence the beginning of our sample). ${ }^{14}$ We obtain public offerings of debt, equity and convertibles from the Thomson Financial SDC new issues database. ${ }^{15}$

A private placement is a private sale of unregistered securities by a public company to a selected group of individuals or institutional investors without general investor solicitation. These sales are typically made to a small number of investors (the median (mean) number of investors in our private equity offerings is 3 (5.4)) and are generally conducted in accordance to the "safe harbor" provisions of Regulation D of the 1933 Securities Act. ${ }^{16}$ Prior to negotiations leading up to the sale of securities privately, often investor(s) conducting negotiations with the firm will sign a confidentially agreement that precludes them from trading on any information privately revealed. The use of confidentially agreements in private placements are strongly recommended specially after the passage of Regulation FD, which prohibits the practice of selective disclosure of information (see footnote 3 ).

Private placements of equity-linked securities are also commonly referred to as Private Investments in Public Equity, or PIPEs, and the PlacementTracker database is a comprehensive source of such deals. ${ }^{17}$ This source for private equity is more comprehensive than SDC having 2.5 times as many private equity issues for the same period as SDC. After matching with Compustat and CRSP, and excluding financial companies and regulated firms, we have a total of 1,377 private equity issues and 1,156 private convertible issues made respectively by 838 and 748 different companies.

Our sample of private corporate debt is from the DealScan database. DealScan contains information on term loans and revolving credit lines made to U.S. companies by banks or syndicates of lenders. We include in our sample only long-term commercial loans and revolving credit lines (thus, for example, we

\footnotetext{
${ }^{14}$ Public firms are required to make disclosure about sales of unregistered securities on forms $10-\mathrm{Q}$ and $10-\mathrm{K}$ (item 701 of Regulation S-K), and since August 2004 such disclosures are also required on form 8-K. Moreover, private placements to investors surpassing a five percent ownership threshold have to be disclosed on a schedule 13-D.

${ }^{15}$ We excluded secondary offerings, in which the company is not issuing new shares, and short-term debt offerings (maturity less than one year). We exclude short-term offerings as these are not typically viewed as part of capital structure.

${ }^{16}$ Regulation D is an SEC Rule that allows public companies to issue stock privately, without the need for public registration prior to the sale, to an unlimited number of accredited investors and no more than 35 non-accredited investors.

${ }^{17}$ PlacementTracker is a main provider of PIPE data to market participants including issuers, investors, and placement agents. We exclude from our sample a few transactions classified as common stock shelf sales and equity line arrangements, because they typically require a registration statement to be effective prior to the sale of the stock, technically making them public offerings.
} 
drop 364-day facilities and any other loan with less than one year of maturity). ${ }^{18}$ Companies often borrow using multiple loans or tranches at the same time. In our dataset, we aggregate all tranches into a single transaction or deal adding up the amount of all long-term loans and revolving credit lines. Our final sample of private corporate debt involves 5,609 deals by 2,667 different companies over the 1995-2003 period (mean (median) number of 2.1 (2.0) private debt offerings per company). The most common type of private debt are revolving credit lines ( $78 \%$ of the deals) followed by term loans (18\% of the deals)-deal type was determined based on the type of the largest tranche in case of multiple tranches.

We also include in our dataset Rule 144-A convertible and debt issues, which are also private placements of unregistered securities. Rule 144-A transactions are placements to investors that are all Qualified Institutional Buyers (QIBs)- large institutional investors with over \$1billion under management. Rule 144A placements are more liquid than the typical (Reg D) private deal because QIBs are allowed to trade or resell their securities to other QIBs without registration while private securities placed under Regulation D have resale restrictions. Moreover, 144-A transactions are typically made to a significant number of investors. For example, the median (mean) number of investors in 144A-convertible offerings is 33 (41), while in the private convertible offering it is just $2(3.4)$. In addition, the company often agrees to register 144-A securities a few months after the offering, making these transactions similar to public offerings. Our sample for 144-A convertibles is obtained from the PlacementTracker database (597 deals) and for the 144-A debt offerings is obtained from the SDC new issues database $(1,017$ deals $) .{ }^{19}$

In our analysis we are interested in the security choice-equity, debt, or convertibles-and the market choice-private versus public-a total of six choices. The key distinction we explore between publicly and privately placed securities is that in the later there are fewer investors purchasing securities and the private (unregistered) securities acquired are less liquid. Private placement investors are then likely to have more incentives to produce information and monitor. The institutional details and our data indicates that 144-A issues and public issues are similar while 144-A and private offerings are quite different (see for example the results in Table 2B). Thus throughout most of our analysis we aggregate 144-A and public offerings (we also do the analysis excluding 144-A and the results are similar). We also consider a full eight choice model in which we look separately at the choice of 144-A convertibles and debt.

We match the data obtained from these sources to Compustat and CRSP, to obtain information on

\footnotetext{
${ }^{18}$ We also dropped credit lines whose primary purpose is to back-up commercial paper, as those credit lines are seldom used.

${ }^{19}$ We aggregate multiple deals by the same company and of the same type (i.e., one of the eight security-market choices) that occur within the same month, as we believe that they are likely to be different tranches of the same deal-the procedure serves to combine mostly multiple debt issues.
} 
firm financials and stock prices. Following standard practice in the literature, we excluded from our sample financial firms (SICs 6000-6999) and regulated utilities (SICs 4900-4999). Matching to CRSP and Compustat yields a total of 17,634 transactions during the 1995-2003 period. We drop observations with insufficient stock price information in CRSP $(1,506)$ and without information in Compustat on assets, debt, or earnings at the fiscal year ending before the issue date $(1,851)$. Note that we need data from Compustat for two years prior to the security issue given the lagged debt ratio is computed as debt ratio divided by lagged assets. These requirements give us 13,419 transactions. For these transactions, there are 11,770 observations with data on the marginal tax rate, 10,523 observations with data on corporate governance and 11,209 observations with IBES analyst data. The intersection of these databases yields 8,346 observations used in the regressions.

\section{B. The Variables}

We include variables to proxy for asymmetric information, risk, investment opportunities, market timing and market conditions. These variables are obtained and calculated as follows:

\section{B1. Asymmetric Information}

We match our dataset to IBES to use analyst earnings forecasts as a proxy for asymmetric information. The main idea is that dispersion among analysts' forecasts and analysts' forecast errors are two measures positively correlated with information asymmetry (between managers and investors). Lang and Lundholm (1996) show that both analysts' forecast accuracy and dispersion significantly decrease when firms make more informative disclosures about future earnings (see also Atjintkya et al (1991)). Better firm disclosure reduces information asymmetry and thus we expect a positive relation between both dispersion and forecast error and information asymmetry. Note that information disclosure can also be costly (or not credible because firms want to increase their share price). For example, competitors are also able to observe publicly disclosed information, so public disclosures can potentially reduce firm value (James and Wier (1988)).

In our study we use analysts' forecasts for the company's upcoming quarterly earnings release in the IBES summary history database. We compute quarterly earnings surprise as the absolute value of the difference between the median quarterly earnings estimate and the actual quarterly earnings per share, normalized by the stock price at the end of fiscal quarter (we also consider the robustness to alternative normalizations based on the book value of equity per share and earnings per share). A similar approach is used to construct the quarterly dispersion measure: it is the standard deviation of outstanding earnings forecasts normalized by the stock price. Note that this measure is only available if there are at least two 
outstanding earnings forecasts.

Even though all firms in our sample are public, they may have incentives to disclose more information prior to a public issue versus prior to a private issue. To control for this endogeneity and potential change in firms' disclosure policy prior to a financing round, when we build our measures for forecast accuracy and dispersion we drop the most recent quarter before the issue date, and we use the average of the last four quarters ending a quarter before the issue date. Thus the earnings surprise and dispersion measure used for each deal is the mean quarterly earnings surprise and dispersion for the last four quarters ending a quarter before the issue date. The surprise and dispersion measures are trimmed to remove the most extreme $1 \%$ observations. This serves to remove outliers and potentially misrecorded data.

Summary statistics are reported in Table 2A. Note that the surprise measure is available for 11,209 of the transactions ( $85 \%$ of total) and the dispersion measure for 9,793 (75\% of total). The dispersion measure is available for fewer deals as we require at least two earnings forecasts for this measure. Also, note that tests for differences in means and medians reveal that both surprise and dispersion are significantly higher for private than public offerings, consistent with the view that there is more asymmetric information for companies involved in private deals.

\section{B2. Risk}

We use several firm specific variables from Compustat and CRSP. Our measure of risk is a firm's cash flow volatility calculated as the standard deviation of cash flow (operating income before depreciation, Compustat data number: data13) using up to twenty fiscal quarters prior to the deal date.

\section{B3. Investment Alternatives, Taxes and a Firm's Need for Funds}

Our measures of investment alternatives include Tobin's q, which is calculated as the market value of the firm divided by the book value of assets (data6), $R \& D$ divided by lagged property plant and equipment, which is defined as the total of R\&D plus advertising (Compustat data numbers ((data45+data46)/lagged data8). Profitability is operating cash flow before depreciation divided by lagged assets (data13/lagged data6). All of these variables are computed for the last fiscal year ending before the transaction date. We also include a financial distress indicator variable equal to one if Altman's Z-score is less than 1.81 and zero otherwise. Altman (2000) shows that a Z-score below 1.81 is a good predictor of corporate distress.

Other control variables include a firm's debt/asset ratio, calculated as long term debt divided by book value of assets (Compustat data numbers: data9/lagged data6), the log of firm value ( log firm size) which is equal to market value of equity plus book values of preferred stock and total debt (Compustat data numbers: data 24 data 25 + data9 + data34 + data39), and a firm's marginal tax rate. The data on a 
firm's marginal tax rate was kindly provided to us by John Graham and is described in more detail in Graham (1996) and Graham and Lemmon (1998). For our transactions, there are 11,770 observations with data on the marginal tax rate. ${ }^{20}$

We also include a measure of a firm's "need for funds" (its internal funding deficit). This measure is constructed for the year prior to the issue and is calculated as capital expenditures (Compustat data number: data128) plus the change in net working capital (-data302 -data303 -data304 -data305 -data307 +data274 -data312 -data301) less a firm's cash flow from operations (data13). We include this measure to control for the possibility that a firm may go to the private market, not because of asymmetric information or risk, but because it only needs a smaller amount of funds given the private markets may have a smaller fixed cost of raising capital. We also recognize that this measure may be endogenous as a small calculated "need" or deficit may not be indicative of actual need as the firm may also have been constrained in the past. Thus we instrument the measure of a firm's financial need with industry instruments and lagged firm instruments and use the predicted value in our regressions. ${ }^{21}$ We use as instruments median industry Tobin's q, median industry capital intensity (capx divided by sales), lagged firm size (total assets), lagged firm size squared, and lagged profitability. These instruments follow from Maksimovic and Phillips (2004) prediction of external financial dependence.

For all firm-specific constructed variables except Tobin's $q$, we eliminate outliers by dropping the top and bottom one-percent of the sample. We also eliminate firms, after eliminating other outliers, whose lagged book value of assets are less than .1 million dollars and whose Tobin's $q$ is in the 99th percentile or above.

\section{B4. Corporate Governance}

Our proxy for the degree of agency costs of equity is the quality of corporate governance as reflected by the provisions adopted by firms in their charters and bylaws. We follow the approach used by Daines and Klausner (2001) to build a corporate governance measure. They focus on four key antitakeover provisions on the charter and bylaws that erect significant barriers to a hostile acquisition: (1) dual-class shares; (2) a classified (or staggered) board; (3) prohibition of shareholders voting by written consent; and (4) prohibition of shareholders calling a special shareholder meeting. Daines and Klausner (2001) argue that (2) and (3) are almost perfect substitutes so there is a shareholder voting restriction if and only if (3) and (4) are both in place.

\footnotetext{
${ }^{20}$ Like Graham (1996), we use the marginal tax rate after deductions for depreciation, interest and leasing expenses.

${ }^{21}$ Note including predicted financial need or deficit is meant to capture the same idea of the fixed cost of raising capital that the issue size would capture without the endogeneity problems that would arise from including a choice variable.
} 
We construct a rank level ordering measuring the quality of corporate governance following Daines and Klausner (2001, pg.116): 1 (worst), if the firm has dual-class shares or has a classified board and a shareholder voting restriction; 2, if the firm has a classified board but no shareholder voting restriction or dual-class shares; 3 , if there is a shareholder voting restriction but not a classified board or dual class shares; and 4 (best), if the firm has none of the restrictive provisions above. ${ }^{22}$

Our data on corporate governance provisions are from three different sources: the Investor Responsibility Research Center (IRRC) dataset on takeover defenses, SharkRepellent.net dataset, and, for a randomly selected sample of 2,000 deals not matched to any of the two datasets, we hand collected the information from the firm's charter and bylaws. The information we use to construct the governance measure is based on the provisions prevailing in the charters and bylaws before the deal date. ${ }^{23}$ The use of takeover defenses in our sample is similar to the results reported in Daines and Klausner (2001), Field and Karpoff (2002), and Gompers et al. (2003). The distribution of the corporate governance measure is, in increasing order, $31 \%$ (worst), $29 \%, 6 \%$, and 34\% (best), for the 10,523 deals with complete information.

\section{B5. Market-Timing and Market Conditions}

Using CRSP data we calculate a firm's cumulative abnormal return 250 days prior to the deal minus the excess return relative to a benchmark portfolio of firms in the same size decile at the end of the year previous to the transaction (we also used risk-adjusted beta decile portfolios for robustness). For each deal we also compute the abnormal excess return using a 10 trading-day window around each issue- the parameters of the market model were estimated in the prior 250 trading days ending at the beginning of the event window.

We include three market variables in our regressions to capture aggregate market conditions in the public markets. We include the Aaa bond yield, a credit spread to capture a distress risk premium, measured as the Baa less the Aaa bond yield- we use the value of these variables as of the end of the previous month before the issue date. To capture conditions in the public equity markets we include the cumulative market return over the 250 days prior to the security issue date. Finally to control for industry-specific factors we include Fama and French industry dummies (17 industry categories) in all regressions we estimate.

\footnotetext{
${ }^{22}$ Daines and Klausner (2001) also make a further refinement based on whether the charter require a 90 days or more advance notice for the nomination of board candidates. We chose not to use this provision because it is not available in the IRRC dataset (also we believe this provision is not as relevant as the other ones).

${ }^{23}$ IRRC data is available for 1990, 1993, 1995, 1998, 2000, and 2002. SharkRepellent.net does not record historical information, so we used the current information for 2,700 deals matched to SharkRepellent.net. However, since firms seldom change provisions in charters and bylaws, we believe that this procedure is not likely to introduce significant measurement errors.
} 


\section{Results}

\section{A. The Sample}

Table 1 summarizes our sample of public firms and their issue decisions by year and for the entire period. We present data for eight different security types: public equity, convertibles and debt, private equity, convertibles and debt, and Rule 144-A debt and convertibles. The total amount raised was over $\$ 2.9$ trillion and the mean (median) amount raised by each deal is also large, representing $23 \%(13 \%)$ of the total firm value. There are a total of 4,267 different firms in our final sample, and the median firm financed 2 times during the period (most of the multiple issues are multiple debt offerings by the same company).

\section{Insert Table 1 here}

Table 1 shows several important facts. First, private equity and private convertible issues are a substantial fraction of securities issued by public companies. This fraction has also been increasing over time with the number of private equity issues exceeding public equity issues from the year 2000 to 2003, the last year of our database. Second, the number of private convertibles is greater than the number of public convertibles for all years since 1995. ${ }^{24}$ The table shows that while private debt issues are larger than public debt issues, private equity issues are smaller and represent a smaller fraction of firm value. Third, the size of private equity issues and the size of issuers has also grown sharply in the later years. In later years the size of private equity issues on average is almost $25 \%$ of the size of an average public equity issue. Finally, Table 1 shows that Rule 144-A debt and convertible issues are closer in size to public debt and convertible issues versus private issues.

Table 2A summarizes the major firm- and market-specific variables that we examine. We present summary statistics in this table for the whole sample and also for each of the eight security categories. We present means, standard deviations and the number of observations for each variable. Table $2 \mathrm{~B}$ presents t-statistics testing whether the means and Mann-Whitney tests of whether the medians from Table $2 \mathrm{~A}$ are different across issue types.

\section{Insert Table 2A and Table 2B here}

Tables $2 \mathrm{~A}$ and $2 \mathrm{~B}$ show several interesting and significant patterns across the variables. First, columns one and two show our measures of asymmetric information, analyst earnings surprise and dispersion, are

\footnotetext{
${ }^{24}$ Kaplan and Stromberg (2002) report that convertible preferred are the most common type of securities used in venture capital financings.
} 
both significantly higher (test statistics for significant differences in means and medians are presented in Table 2B) for securities issued in the private market. Measures of corporate governance are also higher in the private equity, convertible and debt markets. Tables $2 \mathrm{~A}$ and $2 \mathrm{~B}$ also show that private firms are smaller, have higher cash flow volatility (our measure of risk), higher R\&D ratios and higher Tobin's qs versus private securities of the same security type. Firms that issue in the private market, however, have lower profitability and higher measure of financial distress despite having less debt. While private convertible issuers are sharply different from public issuers, issuers of convertibles in the 144-A market are not significantly different for most variables from public issuers. They are also closer to public debt issuers than they are to private debt issuers.

The picture that emerges from these summary statistics is that public issuers in the private market are smaller, highly valued, and less profitable versus public issuers that have higher measures of our proxies for asymmetric information. This conclusion is true for public firms irrespective of the security type. Finally, issuers in the public equity and convertible markets issue after a period of high cumulative abnormal returns - reinforcing the conclusions of Asquith and Mullins (1986) about market timing. Also especially interesting, and consistent with the classic trade-off theory, issuers of debt are more profitable - especially when we compare issuers of private debt to issuers of private equity and private convertibles - who have significantly negative operating cash flows.

\section{B. Stock Market Response}

We now present the stock market reactions to each type of security issuance decision. Table 3 presents the results from cross-sectional regressions of the cumulative abnormal returns on issue type and issuer characteristics. We run regressions for equity, convertibles and debt separately to examine the differences across markets, conditional on security type.

\section{Insert Table 3 here}

Inspection of Table 3 models (1), (3), and (5) reveals results consistent with previous event studies. We regress the 10 trading-day CAR around the issue on the private and public dummies and other control variables. The market reaction to public equity, convertibles and debt are negative while the market reaction to private equity is significantly positive, consistent with Wruck (1989), Hertzel and Smith (1993), and Allen and Phillips (2000). For private convertibles and private debt coefficients are insignificantly different from zero.

In models (2), (4), and (6) we add the forecast error interacted with the private public dummies to 
explore the hypothesis $A S Y$ 4. Inspection of Table 3 reveals that the overall reaction to private equity is still positive while the reaction to public equity issues is negative. The significant positive interaction variable between earnings surprise and private issues in the equity markets is consistent with the market valuing the new information conveyed by private investor purchases of securities. Finally, the results also show that firms that issue equity after a large runup in the stock price suffer a negative reaction, consistent with the market believing that equity issuers are timing the market.

\section{Does the Public-Private Distinction Matter?}

Before we present our models which recognize the public-private market explicitly, we first examine results where we make no market distinction. In Table 4 we present results of a logit model where we combine the private and public equity and also the private and public debt. In this model the dependent variable is equal to one if the firm issues equity and zero if the firm issues debt. We also combine the convertible preferred stocks into the equity category and the convertible bonds into the debt category. This approach closely resembles what one would get using a firm's statement of cash flows to infer security issuance when one does not know the market in which the security is sold. Comparison of these results with the results in which we break out the specific market in which a security is sold, allow us to check whether a different sample is driving our results.

\section{Insert Table 4 here}

Examination of the results in Table 4 show that when we combine public and private equity and public and private debt, none of our asymmetric information variables are significant. In addition the governance variable is not significant either. The finding of insignificance for the asymmetric information variables when we do not identify the choice of market in which securities are sold is consistent with the results of previous studies. Note that the results for risk, investment opportunities, and taxes are also consistent with previous studies.

\section{Logistic Regressions of Security-Market Choice}

In this section we present and discuss our models of security issuance which explicitly identify the market in which the security is sold. We estimate the two models presented in section 2 . First, we estimate the security-market nested logit model (Model 1), and the market-security nested logit model (Model 2). We also estimate and present an eight choice model where we include separately securities issued under Rule 144-A.

Before moving to a nested logit model, we estimated a simple multinomial logit model where firms 
simultaneously choose both the security and market. In order for this model to present valid coefficient estimates, the choices must satisfy the independence of irrelevant alternatives (IIA). This assumption holds if when you omit one security category, the other security probabilities increase proportionately. We conducted several different Hausman tests (excluding different securities) to examine whether this assumption held and found that it did not. We found that the choices of public versus private in particular were not independent of each other. The nested logit is an alternative that does not require this independence assumption across choices that are not in the same group (or nest). (For comparison we still do present the results from the multinomial logit model in an appendix available from the authors (Tables A1 and A2)). Examining the coefficients of the multinomial logit model and comparing them to the nested logit models (in Tables 5 and 7 ), we found that while there are differences in magnitude between the multinomial and the nested logit models (the coefficients and marginal effects from the multinomial model are actually larger in magnitude than the ones from the nested model), the good news is that the signs and significance across the multinomial and nested logit models for our key asymmetric information and risk variables are similar.

Table 5 presents the results of the security-market nested logit model (Model 1). ${ }^{25}$ The results presented in Table 5 show that in the first stage when firms choose securities, firms with a high degree of asymmetric information are less likely to choose equity over debt. Second, they are more likely to choose equity and convertibles if they have high risk and investment opportunities. With respect to other firm characteristics, firms are more likely to choose equity and convertibles if they are small and have low operating cash flows. These proxies have also been used to capture firm risk and investment opportunities by other studies. Similar to the results by Asquith and Mullins (1986) and Lucas and McDonald (1990), the positive significant coefficient on a firm's past year abnormal returns shows that a firm is more likely to issue equity when the firm's stock price has risen recently. The overall results are consistent with asymmetric information and high risk (and thus agency problems of debt) causing firms to be more likely to issue equity. The positive coefficients in the equity column for the Aaa bond rate and the credit spread, Baa-Aaa, are consistent with the firm choosing to issue equity the more costly debt becomes and the higher the default risk spread.

\section{Insert Table 5 here}

\footnotetext{
${ }^{25}$ Another evidence that the multinomial logit model is not appropriate versus this nested logit model is that the hypothesis that the inclusive value parameters $\lambda_{k}$ for each nest (see Appendix) are all jointly equal to one was strongly rejected (p-value $=.015)$. We also note that all the inclusive value parameters are in the interval $0-1$, which makes the nested logit models consistent with value maximization.
} 
Examining, the choice between public and private in the second stage, we see that our measure of asymmetric information is positively related to the decision to issue private securities - especially so for equity. This result is consistent with Hypothesis $A S Y 1$. The ordering of the coefficients also statistically satisfies Hypothesis $A S Y 2$ which states that as the extent of information asymmetry increases the firm is more likely to switch to issue private securities when issuing securities that are more information-sensitive. The coefficient on analyst earnings surprise for private equity is 1.06 which is statistically greater than .388 , the coefficient for private convertibles, which in turn is statistically greater than the coefficient for private bank debt of .201.

These results show that recognizing the market in which securities are sold is very important. The positive coefficients on our asymmetric information variable for all security types show that firms that have a high measure of asymmetric information are more likely to choose to issue private securities.

The results for market choice also show that high risk increases the tendency toward private debt relative to public debt - but not so for convertibles. Thus, the results show only limited support to Hypothesis AG2. In addition, examining the effect of corporate governance, the positive and significant coefficient for corporate governance in column 3, indicates that better governance is associated with an increased tendency to issue private equity over public equity. This is perhaps surprising, if one views the private market as providing increased monitoring. For debt the corporate governance variable is insignificant.

Looking at the other control variables for investment opportunities we can see that smaller firms and firms with higher Tobin's $q$ are more likely to issue privately for all security types, and firms with low profitability and a low marginal tax rate are more likely to issue private equity and convertibles relative to their public counterparts. Finally, firms that have had higher abnormal returns over the past year are more likely to issue stock publicly - consistent with a market timing explanation for public equity security issuance. Given that this result holds for public and not private equity it seems convincing evidence of market timing. Thus the picture that emerges is that small, highly valued firms whose stock market performance recently have not been good and whose cash flows are low are more likely to choose to issue privately.

In Table A3 of the appendix - available from the authors - we estimate the same model with analyst forecast dispersion as the measure of asymmetric information. The results are generally similar to those reported using analyst forecast accuracy. One exception is the coefficient on asymmetric information for the choice of private debt which becomes insignificant. However, all other asymmetric information coefficients remain similar in size and significance. This table also shows that firms in distress are less 
likely to issue private debt - result consistent with the view that private lenders and banks do not like to lend to firms already in distress.

The overall conclusions that emerge from Table 5 are consistent with the summary statistics presented earlier. There are sharp differences between public and private issuers in all markets - and an especially sharp distinction between issuers of public and private equity. Firms with a high degree of asymmetric information are more likely to issue privately and issue private equity. Risk and investment opportunities affect the security choice the most with high risk firms issuing equity and convertibles. Risk has a positive effect on the tendency to issue private debt over public debt but no significant effect for convertibles.

Table 6A examines the economic significance of our results and Table 6B contains measures of goodness of fit by security - showing how well the model predicts actual observed choices. To compute the economic effects we use the estimated model and associated coefficients from our results in Table 5. We first present the marginal significance of our primary nested logistic specifications and then we graphically show the overall significance of our results in the next subsection. Table 6A presents the marginal significance of our results. For each variable, we compute the predicted probability of each of the six firm-level choices at two points, one-half standard deviation above and below, around each individual sample values. We then average over all firms in the sample. Specifically, we compute, for each variable $k$ and for each choice of security $j$, the average marginal effect (averaged over all firms): $m_{j}^{k}=\sum_{i \in N}\left[P_{j}\left(x_{i}+\frac{1}{2} s d_{k}\right)-P_{j}\left(x_{i}-\frac{1}{2} s d_{k}\right)\right] / N$.

\section{Insert Table 6A here}

Table $6 \mathrm{~A}$ shows there is significant variation in the predicted probability of security issuance as we vary each variable. Table $6 \mathrm{~A}$ shows that if we increase our measure of asymmetric information, analyst forecast error, by one standard deviation, the predicted probability of public equity decreases by 7.0 percentage points and the predicted probability of private debt, private convertibles and private equity go up by 8.2 percentage points with a total variation across the six choices of 16.4 percentage points. Security choice is also highly sensitive to risk and investment variables, such as R\&D to net fixed assets and profitability, with total variation in the predicted probability of issuance of 13.4 and 18.3 percentage points respectively. The table also shows firms are more likely to issue public equity and not private equity after their stock has risen recently. The probability of a public equity issue increases by 4.4 percentage points after a one standard deviation movement in the one-year cumulative abnormal stock return, with a total variation in the predicted probability of 17.8 percentage points. This result is consistent with market timing of equity issues to the public market versus timing of both private and public equity issues after market runups. 
Finally, the table also shows that corporate governance is not economically important to security issuance decisions.

Table 6B contains measures of goodness of fit of our model as it shows how well the nested logit model from Table 5 does in predicting the actual observed choice. The table contains the observed choice in the rows and the predicted choice in each column. The predicted choice is the one with maximum probability among the six choices using the coefficient estimates from Table 5. The first row of each cell gives the number predicted to choose the security given in the column header. The second row gives the percentage predicted to choose that security versus the actual choice. The third row gives the percentage of observed, predicted pairs divided by the overall number predicted to issue that security.

\section{Insert Table 6B here}

Table $6 \mathrm{~B}$ shows that our model from Table 5 overall does very well in predicting security issues for most securities. The model does very well in predicting public debt (61 percent predicted correctly), private debt (78 percent predicted correctly) and private equity (53 percent predicted correctly). Perhaps not surprisingly the model does less well in predicting convertible securities as they are a blend of equity and debt. Interestingly, the model predicts many public equity issues as private debt, perhaps because private debt gives firms flexibility like public equity.

\section{E. Graphical Presentation of our Results}

The logistic distribution has an S-shape and the marginal effects are mostly concentrated on the tails of the distribution with sharp increases around the cut-off levels. Thus the average marginal effects of Table $6 \mathrm{~A}$ may be underestimating the extent of the impact of changes on firm characteristics on the financing choices. In order to explore this issue further, we graphically depict our predicted results. We show how firms in different size classes (Figure 1) and issuing each of the six different type of securities (Figure 2) are predicted to change their issuance behavior as we vary our two primary variables, asymmetric information and risk. We plot the issuance choice with maximum probability, for a "hypothetical firm" as only risk and asymmetric information changes.

Figure 1 shows the predicted probability of security issuance using coefficient estimates from our model in Table 5. We present graphs for firms of different sizes, given the importance of size in the model. We construct three different size groups, small, below the 33rd percentile, medium, between the 33rd and 66th percentile and large, above the 66th percentile. We plot the predicted security issued (maximum probability of issuance) as we move our asymmetric information and risk variables +/- ten standard 
deviations away from their size-based mean values, keeping all other variables at their mean values for each size group. Risk (volatility of cash flows) is on the y-axis and asymmetric information (earnings surprise relative to analyst forecasts) is on the $\mathrm{x}$-axis. $\mathrm{PuE}(\mathrm{PrE})$ is public (private) equity, $\mathrm{PuC}(\mathrm{PrC})$ is public (private) convertibles, $\mathrm{PuD}(\mathrm{PrD})$ is public (private) Debt. Dark and light shading within regions represent the security with predicted probability greater than 50 percent and between 0-50 percent higher than the next highest security.

\section{Insert Figure 1 here}

Figure 1 clearly shows that as asymmetric information increases firms are more likely to issue privately. Small firms with both high risk and asymmetric information are more likely to issue private equity and convertibles. Medium size firms are more likely to issue private debt for high levels of asymmetric information and low levels of risk, and more likely to issue private convertibles for both high levels of asymmetric information and risk. As shown in the graphs for medium and large firms, conditional upon issuing publicly, firms with the highest degree of asymmetric information are more likely to issue public debt - consistent with the Myers's pecking order. However, as before, when issuing privately the security choice is more nuanced. Firms with low risk but high asymmetric information are likely to issue private debt while firms with the highest levels of risk and asymmetric information issue private convertibles for all three size classes.

In Figure 2 we present graphs of predicted probability of security issuance for firms that actually issued each one of the six securities. For example, in the last of the six graphs in this figure, we take all firms that issue private equity and then examine how their predicted choice might change as we vary our asymmetric information and risk variables +/- ten standard deviations away from their security-based mean values, keeping all other variables at the mean values for private equity.

\section{Insert Figure 2 here}

Inspection of the graphs in Figure 2 reveal that predicted probability of security issuances are markedly different as risk and asymmetric information varies - for each set of firms issuing different types of securities. Considering the first graph for public debt issuers, we can see that the model predicts public debt fairly accurately with public debt predicted to be issued at the means of the data. However, as we move risk and asymmetric information away from their mean values, we get public equity predicted to be chosen for low earnings surprise (asymmetric information) - consistent with a pecking order model - and private 
debt predicted to be chosen for high asymmetric information. Private convertibles are predicted to be chosen for high levels of risk and asymmetric information. Examining the graphs in the middle (graphs 2 and 5) for both public and private convertibles, we can see that the model in Table 5 does not predict these securities very well, as at the mean levels of the variables (the middle of each graph) private debt is predicted to be issued for firms issuing public convertibles and private equity is predicted to be issued by firms actually issuing private convertibles. Examining the fourth and sixth graphs, we can see that the model does very well predicting private debt and private equity. What is especially interesting is that firms that issue private equity and convertibles are rarely predicted to issue debt securities. For low levels of our asymmetric information variable, private equity issuers are predicted to issue public equity and private convertibles for the highest levels of asymmetric information. Note that these graphs hold other variables, including size, at their security-specific means and it is thus a hypothetical experiment as there may not be an actual firm with very high asymmetric information and mean levels of other variables. What the graphs do show, however, especially for straight debt and equity, both public and private, is that there are large regions where the security choice is expected to remain the same.

Overall, it is clear from all graphs in Figure 2 that firms with both high asymmetric information and high risk issue private convertibles and private equity. Firms with lower risk but still high asymmetric information issue private debt. Firms with high risk but low asymmetric information are more likely to issue public equity. All of the graphs quite clearly show that firms move away from issuing public equity and issue other securities as asymmetric information increases. The most important distinction for the decision to issue securities privately is asymmetric information. Risk influences more the type of security that the firm issues conditional upon issuing publicly or privately.

\section{F. Model 2: Testing the Pecking Order}

Table 6 presents the results of our nested logit model 2, which allows correlation within security type (debt, convertibles, equity). Under this model we can test the hypotheses on the pecking order conditional on market choice. Table 6 uses analyst forecast errors as our measure of asymmetric information. ${ }^{26}$

\footnotetext{
${ }^{26}$ In Table A4 of the appendix available from the authors, we present results using analyst forecast dispersion. As before this table omits firms that have less than 2 analysts so the sample is smaller. The results using analyst forecast dispersion as the measure of asymmetric information are generally similar to those of Table 6 for nearly all coefficients. One exception is the coefficient on forecast dispersion for issuing privately in the first stage, which is insignificant. However, all other coefficients on analyst forecast dispersion for the second stage security decisions remain similar in size and significance to those for analyst forecast error in Table 6 . Notably the coefficient on asymmetric information for public equity remains significantly negative and the coefficients on private equity and convertibles remain significantly positive.
} 


\section{Insert Table 7 here}

The results presented in Table 7 show that in the first stage firms with a high degree of asymmetric information and high cash flow volatility are more likely to sell securities in the private market. Examining the results yields similar conclusions to those from in Table 5. Small firms, with high Tobin's $q$, with high R\&D, with lower one year abnormal returns and low profitability are more likely to choose to issue securities privately.

Columns 2 through 5 report the results conditional upon the market. We see that conditional on issuing in the public market, public issuers are more likely to issue public debt relative to public convertibles and public equity when asymmetric information increases. We test Hypothesis $A S Y 3$ formally and find that the coefficient for public equity is significantly lower than both public convertibles and public debt. Thus, the results for public equity are consistent with the Myers's pecking order in the public market. However the coefficient on public convertibles is not significantly different from zero and thus public convertibles do not satisfy the pecking order.

We also find that conditional on issuing in the private market the opposite of the pecking order holds consistent with Fulghieri and Lukin (2001). Hypothesis ASY3 predicting a reversal of the pecking order for the private market is generally supported, as coefficients for asymmetric information for both private convertibles and equity are statistically greater than zero - however we do show a larger coefficient for private convertibles versus private equity. Distress is the another variable that shows a different pattern for public and private markets. Firms issuing privately are more likely to issue equity and convertibles if they have high measures of financial distress. There is no significant relation between distress and security issuance in the public markets. The final relation that differs across the public and private markets, is that when the overall cumulative market return is positive, issuers in the public market have a higher tendency to issue equity, while this effect is partially reversed in the private markets.

With respect to risk and our tests of Hypothesis $A G 1$ for risk, we find that the ordering of sensitivity to risk holds in the public market; it is highest for equity, next highest for convertibles, and lowest for debt and the differences are statistically significant. In the private market both equity and convertibles have a higher sensitivity to risk versus the benchmark of private debt, but the sensitivities of private equity and private convertibles are not statistically different from each other. Thus we find a strict ordering for sensitivity to risk holds in the public market as specified by Hypothesis AG1, while a weak ordering holds in the private market. 


\section{Insert Table 8 here}

Table 8 presents the economic significance of the results in Table 7 holding all variables except the one in the row at their sample means (see section 4.D for computational details). The table shows there is significant variation in the predicted probability of security issuance as we vary each variable. Table 8 shows that if we increase our measure of asymmetric information, analyst forecast accuracy, by one standard deviation, the predicted probability of public equity decreases by 7.8 percentage points and the predicted probability of private debt, private convertibles and private equity go up by 8.8 percentage points and a total variation across the six choices of 17.5 percentage points. Security choice is also highly sensitive to risk and investment opportunity, and variables such as R\&D to net fixed assets and profitability have a large effect on the predicted probabilities, with total variation of 12.7 and 18.3 percentage points respectively. Market timing, measured by the cumulative abnormal stock return, also has a large effect with public equity being more likely to be issued by 4.5 percentage points after a one standard deviation movement in the firm's cumulative abnormal return, with a total variation in predicted probability of 18.7 percentage points.

The overall message that emerges from these tables reinforces the conclusion that the effect of asymmetric information is quite different in the public and private markets and that issuers of public and private securities are quite different. Firms with a high degree of asymmetric information are more likely to issue privately and issue private equity and convertibles. A striking difference is evident for the public market. Conditional upon issuing in the public markets, firms with a high degree of asymmetric information are more likely to issue public debt over public equity. The results reinforce the conclusion that in order to gauge the effect of information on security issuance decisions, it is crucial that one does not combine private and public security issues.

\section{G. Rule 144-A Market}

Table 9 presents the final nested logit specification. In this table we expand the number of markets to estimate separate coefficients for Rule 144-A debt and convertibles issues. In Table 9 we present the results for the security-market nested logit model. We present these results for the dispersion measure of asymmetric information- similar results hold for forecast error as well. We do not present results for the market-security model as they were similar to those in Table 7.

\section{Insert Table 9}

The results for equity and convertibles are similar to those in Table 5. Firms with higher measures of 
asymmetric information are less likely to issue equity. Conditional upon issuing equity and convertibles, they are more likely to issue privately. The results on asymmetric information for issuing privately, conditional upon issuing debt, become insignificant and the results on asymmetric information for securities issued under Rule 144-A are insignificant. The results for risk are similar to the previous results, with the additional result that firms that issue debt are more likely to issue Rule 144-A versus public debt if they have high risk. Other results for debt securities issued under Rule 144-A are that these firms are smaller, less profitable, highly valued, less R\&D intensive than firms issuing in the public debt markets. Overall the results are consistent with firms issuing debt under Rule 144-A being riskier (but with a similar sensitivity to asymmetric information) than firms that issue in the public debt markets.

\section{Conclusions}

In this paper we analyze the public and private security issuance decisions by public companies. Using a comprehensive database of public and private security issues we examine the impact of asymmetric information and agency costs on security issuance decisions. We show that private equity issues are significant in number, especially for smaller firms that potentially have more asymmetric information and higher risk. Our comprehensive sample also shows that private equity and private convertible issues are a substantial fraction of securities issued by public companies. This fraction has also been increasing over time, with the number of private equity issues exceeding public equity issues from the year 2000 to 2003, the last year of our database. Private equity and convertibles issued by public firms comprise 58 percent of their equity and convertibles issues, with the number of private convertibles is greater than the number of public convertibles for all years of our database.

We analyze the factors that are related to the probability a firm chooses to issue public and private equity, public and private convertibles and public and private debt. We have several results on the relations between security issuance decisions and asymmetric information.

1. Firms that have a high measure of asymmetric information, measured by either analyst earnings dispersion or analyst earnings forecast errors, are significantly more likely to issue securities in the private market.

2. Conditional on issuing in the private markets, firms with both high measures of asymmetric information and risk are most likely to issue private convertibles and equity than private debt. 
3. However, conditional upon issuing in the public market, firms with high asymmetric information are more likely to issue debt and less likely to issue equity. Thus, while we show that a pecking order of issuance decisions, where firms with asymmetric information issue debt, does not hold overall, and is actually reversed in the private market, we do find a such a pecking order in the public market.

4. Our results on market timing indicate that firms are more likely to issue public equity and not private equity after their stock has risen in the past year relative to a benchmark portfolio. This result is consistent with market timing of equity issues to the public market versus just timing of equity issues overall.

These results establish that private markets are quite different from public markets on many different dimensions. Economic significance of the results indicates that asymmetric information is one of the most significant and economically important factors that influences security issuance decisions. The results are consistent with the private issues being sold to investors to provide stronger incentives for information production and also being sold to investors with better ability or incentives to evaluate firm prospects.

Our findings regarding the importance of agency costs for the security-market decision also yields several results:

1. Firms with high risk, that are smaller, highly valued but with low cash flows are more likely to issue equity and convertibles in both public and private markets.

2. The likelihood of issuing private bank debt versus public debt increase with increases in risk and investment opportunities.

3. Firms with high-quality corporate governance are more likely to issue in the private equity market. However corporate governance is economically not very important to the issuance decision.

Our results also show support for the classic trade-off theory. Taxes, profitability, and financial distress impact security choice. Firms with high profitability, a high marginal tax rate and also a low financial distress indication are significantly more likely to issue private debt.

Considering all the security-market choices rather than a more limited choice set thus allows us to draw several novel implications. In particular, we show that firms facing higher levels of asymmetric information shift from public to private debt for moderate levels of risk but for high levels of risk they shift toward private convertibles or equity. Overall, the results are consistent with private equity and convertibles being 
more likely to be issued by firms with asymmetric information and to mitigate potential agency conflicts between equity and debt holders. Our results indicate that the security and market issuance choice is not a "one-horse" shay and securities are issued to solve multiple problems. 


\section{Appendix}

The most commonly used model is the multinomial logit model. This model assumes that the errors $\varepsilon_{i j}$ are i.i.d. extreme value distribution (the cumulative distribution is $e^{-e^{-\varepsilon_{j}}}$ ). McFadden (1973) has shown under this assumption for the errors the firm maximization behavior lead to

$$
\operatorname{Pr}[Y=j]=\frac{e^{b_{j} x_{i}}}{\sum_{k \in J} e^{b_{k} x_{i}}}
$$

This model implies that the independence of irrelevant alternatives holds. The economic content of this assumption is that omission of one of the categories will lead to a proportionate increase in the remaining alternatives.

A more general model that we consider is a nested logit model. Note that the value function can be decomposed into two observed parts: For Model 2 presented in the text, the first part is the value from making the private-public choice $W_{\text {priv }}=b_{\text {priv }} x$ (public has been normalized to zero), and the other part is the additional value from making a specific security choice within the nest $Y_{j}=b_{j} x$ (debt has been normalized to zero). The value of choice $j$ is then $V_{j}=W_{k}+Y_{j}+\varepsilon_{j}$.

To estimate the nested models presented in the text we have to make assumptions about the distribution of the errors. We will allow for a generalized extreme value distribution (GEV). The most widely used GEV model is a nested logit model, where the errors have the following cumulative distribution:

$$
\exp \left(-\left(e^{-\varepsilon_{e} / \lambda_{\text {priv }}}+e^{-\varepsilon_{c} / \lambda_{\text {priv }}}+e^{-\varepsilon_{d} / \lambda_{\text {priv }}}\right)-\left(e^{-\varepsilon_{E} / \lambda_{\text {pub }}}+e^{-\varepsilon_{C} / \lambda_{\text {pub }}}+e^{-\varepsilon_{D} / \lambda_{\text {pub }}}\right)\right)
$$

For any two alternatives in two different nests, say private debt and public convertibles, the errors are uncorrelated, $\operatorname{cov}\left(\varepsilon_{d}, \varepsilon_{C}\right)=0$. But for two alternatives in the same nest the errors are correlated. The parameter $1-\lambda_{k}$ can be interpreted as the correlation among choices in nest $k$. So the inclusive value parameter $\lambda_{k}$ measures the degree of independence for the portions of the value for alternatives within nest $k$ (a lower value indicating more correlation). Note that if $\lambda_{k}=1$ for all nests $k$ then the alternatives are independent and the multinomial logit model is appropriate.

The probability that a choice $j$ is made is $P(j)=P(j \mid k) \cdot P(k)$, where $k$ is the choice of nest (public, private). It can be shown that value maximization implies:

$$
\begin{aligned}
& P(\text { elpriv })=\frac{e^{b_{e} x}}{1+e^{b_{e} x}+e^{b_{c} x}} ; P(c \mid \text { priv })=\frac{e^{b_{c} x}}{1+e^{b_{e} x}+e^{b_{c} x}} ; P(d \mid \text { priv })=\frac{1}{1+e^{b_{e} x}+e^{b_{c} x}} \\
& P(E \mid \text { pub })=\frac{e^{b_{E} x}}{1+e^{b_{E} x}+e^{b_{C} x}} ; P(C \mid \text { pub })=\frac{e^{b_{C} x}}{1+e^{b_{E} x}+e^{b_{C} x}} ; P(D \mid \text { pub })=\frac{1}{1+e^{b_{E} x}+e^{b_{C} x}}
\end{aligned}
$$


and

$$
P(\text { priv })=\frac{e^{b_{\text {priv }} x+\lambda_{\text {priv }} I_{\text {priv }}}}{e^{\lambda_{\text {pub }} I_{\text {pub }}}+e^{b_{\text {priv }} x+\lambda_{\text {priv }} I_{\text {priv }}}} ; P(\text { pub })=\frac{e^{\lambda_{\text {pub }} \boldsymbol{I}_{\text {pub }}}}{e^{\lambda_{\text {pub }}{ }_{\text {pub }}}+e^{b_{\text {priv }} x+\lambda_{\text {priv }} I_{\text {priv }}}}
$$

where $I_{k}$ are the inclusive value for nest $k$

$$
I_{\text {priv }}=\ln \left(1+e^{b_{e} x}+e^{b_{c} x}\right) \text { and } I_{\text {priv }}=\ln \left(1+e^{b_{E} x}+e^{b_{C} x}\right)
$$

The inclusive values have an important economic interpretation: $\lambda_{k} I_{k}$ is the expected value that the firm receives from the choice among the alternatives in the nest $k$.

Note that the odds ratio among to alternatives, say equity and debt, within the same branch, say public, is

$$
\frac{P_{E}}{P_{D}}=\frac{\operatorname{Pr}[Y=E \mid \text { public }]}{\operatorname{Pr}[Y=D \mid p u b l i c]}=e^{b_{E} x}
$$

so the coefficient $e^{b_{E}^{k}}$ describe the change in the odds ratio associated with an increase in $x_{k}$.

Another nested logit specification is the one in which the firm first choose the security and then the market (model 1 in the text). In this case the errors have the following distribution

$$
\exp \left(-\left(e^{-\varepsilon_{e} / \lambda_{E}}+e^{-\varepsilon_{E} / \lambda_{E}}\right)-\left(e^{-\varepsilon_{c} / \lambda_{C}}+e^{-\varepsilon_{C} / \lambda_{C}}\right)-\left(e^{-\varepsilon_{d} / \lambda_{D}}+e^{-\varepsilon_{D} / \lambda_{D}}\right)\right)
$$

Note that under this specification the odds ratio

$$
\frac{P_{e}}{P_{E}}=\frac{\operatorname{Pr}[Y=e \mid \text { equity }]}{\operatorname{Pr}[Y=E \mid \text { equity }]}=e^{a_{\text {priv }, e} x}
$$

so the coefficient $e^{a_{\text {prive }}^{k}}$ describe the change in the odds ratio associated with an increase in $x_{k}$.

We estimate the parameters of these models using maximum likelihood estimation. 


\section{REFERENCES}

Ajinkya, Bipin B., Roland K. Atiase, and Michael J. Gift, 1991, Volume of trading and the dispersion in financial analysts earnings forecasts, The Accounting Review 66(2): 389-401.

Allen, Jeffrey, and Gordon M. Phillips, 2000, Corporate Equity Ownership, Strategic Alliances and Product Market Relationships, Journal of Finance 55, 2791-2815.

Altman, Edward, 2000. Predicting Financial Distress of Companies: Revisiting the Z-Score and Zeta Models, Working paper, New York University.

Asquith, Paul, and David W. Mullins, 1986, Equity Issues and Offering Dilution, Journal of Financial Economics 15, 61-89.

Baker, Malcolm and Jeffrey Wurgler, 2002, Market Timing and Capital Structure, Journal of Finance 57, $1-32$.

Barclay, Michael J., Clifford G. Holderness, and Dennis P. Sheehan, 2003, Private Placements and Managerial Entrenchment, Working paper, University of Rochester.

Blackwell, David, and David Kidwell, 1988, An Investigation of the Cost Differences Between Public Sales and Private Placements of Debt, Journal of Financial Economics 22, 253-278.

Boyd, John, and Edward C. Prescott, 1986, Financial Intermediary Coalitions, Journal of Financial Theory 38, 211-232.

Brennan, Michael J., and Allan Kraus, 1987, Efficient Financing Under Asymmetric Information, Journal of Finance, 1225-1243.

Brennan, Michael J., and E.S. Schwartz, 1987, The Case for Convertibles, Journal of Applied Corporate Finance 1, 55-64.

Brophy, David J., Paige P. Ouimet, and Clemens Sialm, 2004, PIPE Dreams? The Stock Price Performance of Companies Issuing Private Investments in Public Equity, Working paper, University of Michigan Business School.

Cantillo, Miguel, and Julian Wright, 2000, How Do Firms Choose Their Lenders? An Empirical Investigation, Review of Financial Studies 13, 155-189.

Chang, Xin, Sudipto Dasgupta, and Gilles Hilary, 2004, Analyst Coverage and Capital Structure Decisions, Working paper, Hong Kong University of Science and Technology.

Chaplinsky, Susan, and David Haushalter, 2003, Financing Under Extreme Uncertainty: Evidence from PIPEs, 2003, Working paper, University of Virginia. 
Chemmanur, Thomas, and Paolo Fulghieri, 1999, A Theory of Going-Public Decision, The Review of Financial Studies 12 (2), 249-279.

Daines, Robert, and M. Klausner (2001), "Do IPO Charters Maximize Firm Value? Antitakeover Protection in IPOs, Journal of Law, Economics, and Organization 17, 83-120.

Denis, David J., and Vassil T. Mihov, 2003, The Choice Between Bank Debt, Non-Bank Private Debt and Public Debt: Evidence from New Corporate Borrowings, Journal of Financial Economics 70(1), $3-28$.

Diamond, Douglas W., 1984, Financial Intermediation and Delegated Monitoring, Review of Economic Studies, 393-414.

Diamond, Douglas W., 1991, Monitoring and Reputation: The Choice Between Bank Loans and Directly Placed Debt, Journal of Political Economy 99, 689-721.

Fama, Eugene, 1985, What is different about Banks?, Journal of Monetary Economics 17, 239-249.

Fama, Eugene and Kenneth French, 2002, Testing trade-off and pecking order predictions about dividends and debt, Review of Financial Studies 15 (1), 1-33.

Faulkender, Michael, and Mitchell Petersen, 2005, Does the Source of Capital Affect Capital Structure? Review of Financial Studies, forthcoming.

Field, Laura, and Jonathan Karpoff, 2002, Takeover Defenses of IPO Firms, Journal of Finance 57, 1857-1889.

Frank, Murray Z., and Vidhan K. Goyal, 2003, Testing the pecking order theory of capital structure, Journal of Financial Economics 67, 217-248.

Fulghieri, Paolo, and Dmitry Lukin, 2001, Information production, dilution costs, and optimal security design, Journal of Financial Economics 61, 3-42.

Graham, John R., 1996, Debt and the marginal tax rate, Journal of Financial Economics 41, 41-73.

Graham, John R., and Michael Lemmon, 1998, Measuring Corporate Tax Rates and Tax Incentives: A New Approach, Journal of Applied Corporate Finance 11, 54-65.

Gompers, Paul, Joy Ishii, and Andrew Metrick, 2003, Corporate Governance and Equity Prices, Quarterly Journal of Economics 118, 107-155.

Gorton, Gary, and Andrew Winton, 2003, Financial Intermediation, Handbook of the Economics of Finance, $459-460$.

Green, Richard C., 1984, Investment Incentives, Debt, and Warrants, Journal of Financial Economics 13, 115-136. 
Grossman Sanford, and Oliver Hart, 1982, Corporate Financial Structure and Managerial Incentives, in McCall, editor, Economics of Information and Uncertainty.

Helwege, Jean, and Nellie Liang, 1996, Is there a pecking order? Evidence from a panel of IPO firms, Journal of Financial Economics 40, 429-458.

Hertzel, Michael, and Richard L. Smith, 1993, Market discounts and shareholder gains for placing equity privately, Journal of Finance 48, 459-485.

Houston, Joel, and Christopher James, 1996, Bank Information Monopolies and the Mix of Private and Public Debt Claims, Journal of Finance 51, 1863-1889.

Hovakimian, A., T. Opler, and S. Titman, 2001, The debt-equity choice, Journal of Financial and Quantitative Analysis 36 (1), 1-24.

James, Christopher and Peggy Wier, 1988, Are bank loans different? Some evidence from the stock market, Journal of Applied Corporate Finance 1, 46-54.

Jensen, Michael, 1986, The Agency Costs of Free Cash Flow: Corporate Finance and Takeovers, American Economic Review, 76(2).

Jensen, Michael, and William Meckling, 1976, Agency Costs of Free Cash Flow, Corporate Finance, and Takeovers, American Economic Review 76(2), 323-329.

Jensen, Michael, and Richard Ruback, 1983, The Market for Corporate Control: The Scientific Evidence, Journal of Financial Economics 11.

Kahn, Charles and Andrew Winton, 1998, Ownership Structure, Speculation, and Shareholder Intervention, Journal of Finance 53, 99-129.

Kaplan, Steven N., and Per Stromberg, 2002, Financial Contracting Theory Meets the Real World: An Empirical Analysis of Venture Capital Contracts, Review of Economic Studies, 2003, 70, 243-281.

Kayhan, Ayla and Sheridan Titman, 2004, Firms' Histories and Their Capital Structures, Working paper, University of Texas at Austin.

Korajczyk, R., and A. Levy, 2003, Capital Structure Choice: Macroeconomic conditions and financial constraints, Journal of Financial Economics 68, 75-109.

Korajczyk, Robert, Deborah Lucas, and Robert McDonald, 1991, The Effect of Information Releases on the Pricing and Timing of Equity Issues, Review of Financial Studies 4(4), 685-708.

Krishnaswami, Sudha, Paul A. Spindt, and Venkat Subramaniam, 1999, Information Asymmetry, Monitoring and the Placement Structure of Corporate Debt, Journal of Financial Economics 51, 407-434. 
Laitin, Sari and John Houston, 2000, "The SEC Adopts New Regulations to Curb Selective Disclosure", http://rkmc.com/article.asp?articleId=137, Robins, Kaplan, Miller and Ciresi L.L.P.

Lang, Mark H. and Russell J. Lundholm, 1996, Corporate disclosure policy and analyst behavior, Accounting Review 71(4), 467-492.

Leary, Mark, and Michael R. Roberts, 2004a, Do Firms Rebalance Their Capital Structures?, Working paper, Duke University.

— , 2004b, Financial Slack and Tests of the Pecking Order's Financing Hierarchy, Working paper, Duke University.

Lemmon, Michael, and Jaime Zender, 2002, Debt Capacity and Tests of Capital Structure Theories, Working paper, University of Utah.

Lucas, Deborah, and Robert McDonald, 1990, Equity Issues and Stock Price Dynamics, Journal of Finance 45, 1019-1043.

MacKie-Mason, Jeffrey K., 1990, Do Firms Care Who Provides Their Financing?, in Asymmetric Information, Corporate Finance, and Investment, R. Glenn Hubbard, ed. Chicago: University of Chicago Press, pp. 63-104.

Maksimovic, Vojislav, and Gordon M. Phillips, 2004, "The Industry Life-Cycle, Acquisitions and Investment: Does Firm Organization Matter?" Working paper, University of Maryland.

Maksimovic, Vojislav, and Pegaret Picher, 1999, Private versus Public Offerings: Optimal Selling Mechanisms with Adverse Selection, Working paper, University of Maryland.

Masulis, Ronald W,. and Ashok N. Korwar, 1986, Seasoned Equity Offerings: An Empirical Investigation, Journal of Financial Economics 15, 91-118.

Mikkelson, Wayne, and Megan Partch, 1986, Valuation Effects of Security Offerings and the Issuance Process, Journal of Financial Economics 15, 31-60.

Myers, Stewart C., and Nicholas S. Majluf, 1984, Corporate financing and investment decisions when the firm has information that investors do not have, Journal of Financial Economics 13, 187-221.

Myers, Stewart C., 1977, Determinants of corporate borrowing, Journal of Financial Economics 5, 147175.

Myers, Stewart C., 1984, The capital structure puzzle, Journal of Finance 39, 575-592.

Novaes, Walter and Luigi Zingales, 1995, Capital structure choice when managers are in control: entrenchment versus efficiency, NBER working paper 5384 . 
Rajan, Raghuram, 1992, Insiders and Outsiders: The Choice Between Informed and Arm's-Length Debt, Journal of Finance 47, 1367-1406.

Ramakrishnan, Ram, and Anjan Thakor, 1984, Information Reliability and a Theory of Financial Intermediation, Review of Economic Studies, 51(3), 415-432.

Shleifer, Andrei, and Robert Vishny, 1989, Managerial Entrenchment: The Case of Manager-Specific Investments, Journal of Financial Economics 25, 123-140.

Shyam-Sunder, Lakshmi, and Stewart C. Myers, 1999, Testing static tradeoff against pecking order models of capital structure, Journal of Financial Economics 51 (2), 219-244.

Stein, Jeremy, 1992, Convertible Bonds as Back Door Equity Financing, Journal of Financial Economics $32,3-21$.

Titman, S., and R. Wessels, 1988, The determinants of capital structure, Journal of Finance 43, 1-19.

Wruck, Karen H., 1989, Equity ownership concentration and firm value: Evidence from private equity financings, Journal of Financial Economics 23, 3-28

Wu, YiLin, The Choice of equity-selling mechanisms, Journal of Financial Economics, forthcoming.

Zwiebel, Jeffrey, 1996, Dynamic Capital Structure under Managerial Entrenchment, American Economic Review 86(5), 1197-1215. 
Table 1

Number and Gross Proceeds of Securities Issued by Year

Table shows the number of issues, the total gross proceeds raised in millions of dollars, and the mean amount raised as a percent of firm value (\%FV) for each year and security-market choice. The source of information is SDC (all public issues and 144-A debt issues), DealScan (private debt), and PlacementTracker (private equity and convertibles and 144-A convertibles). Securities are included if from public companies matched to Compustat and CSRP (financials and regulated utilities are excluded)

\begin{tabular}{|c|c|c|c|c|c|c|c|c|c|c|}
\hline \multicolumn{2}{|l|}{ Year } & \multicolumn{3}{|c|}{ Public } & \multicolumn{2}{|c|}{ 144-A } & \multicolumn{3}{|c|}{ Private } & \multirow[b]{2}{*}{ Total } \\
\hline & & Debt & Convertibles & Equity & Debt & Convertibles & Debt & Convertibles & Equity & \\
\hline \multirow{3}{*}{1995} & $\mathrm{~N}$ & 210 & 25 & 217 & 46 & 21 & 500 & 30 & 50 & 1,099 \\
\hline & $\$ M M$ & 38,735 & 3,277 & 13,791 & 6,328 & 2,480 & 154,573 & 456 & 656 & 220,295 \\
\hline & $\% F V$ & $8 \%$ & $27 \%$ & $24 \%$ & $36 \%$ & $18 \%$ & $33 \%$ & $17 \%$ & $13 \%$ & $25 \%$ \\
\hline \multirow{3}{*}{1996} & $\mathrm{~N}$ & 233 & 32 & 274 & 71 & 41 & 659 & 108 & 64 & 1,482 \\
\hline & $\$ M M$ & 53,354 & 6,053 & 16,943 & 11,643 & 5,397 & 198,719 & 1,660 & 628 & 294,398 \\
\hline & $\% F V$ & $10 \%$ & $19 \%$ & $26 \%$ & $45 \%$ & $25 \%$ & $32 \%$ & $21 \%$ & $16 \%$ & $26 \%$ \\
\hline \multirow{3}{*}{1997} & $\mathrm{~N}$ & 224 & 26 & 224 & 186 & 69 & 729 & 155 & 66 & 1,679 \\
\hline & $\$ M M$ & 59,355 & 3,792 & 14,011 & 37,009 & 11,433 & 246,692 & 2,560 & 1,135 & 375,987 \\
\hline & $\% \mathrm{FV}$ & $8 \%$ & $21 \%$ & $24 \%$ & $32 \%$ & $26 \%$ & $32 \%$ & $13 \%$ & $13 \%$ & $25 \%$ \\
\hline \multirow{3}{*}{1998} & $\mathrm{~N}$ & 289 & 18 & 146 & 181 & 46 & 640 & 130 & 78 & 1,528 \\
\hline & $\$ M M$ & 89,008 & 4,496 & 14,509 & 49,079 & 10,776 & 142,502 & 1,020 & 664 & 312,054 \\
\hline & $\% F V$ & $6 \%$ & $11 \%$ & $20 \%$ & $31 \%$ & $15 \%$ & $37 \%$ & $14 \%$ & $11 \%$ & $24 \%$ \\
\hline \multirow{3}{*}{1999} & $\mathrm{~N}$ & 184 & 21 & 173 & 118 & 36 & 603 & 148 & 170 & 1,453 \\
\hline & $\$ M M$ & 69,356 & 11,265 & 22,442 & 46,908 & 9,808 & 131,333 & 4,534 & 2,211 & 297,855 \\
\hline & $\% F V$ & $8 \%$ & $9 \%$ & $22 \%$ & $22 \%$ & $15 \%$ & $37 \%$ & $16 \%$ & $14 \%$ & $25 \%$ \\
\hline \multirow{3}{*}{2000} & $\mathrm{~N}$ & 139 & 22 & 174 & 40 & 64 & 602 & 178 & 221 & 1,440 \\
\hline & \$MM & 58,039 & 11,723 & 30,893 & 32,320 & 20,287 & 172,311 & 9,690 & 7,121 & 342,383 \\
\hline & $\% F V$ & $4 \%$ & $11 \%$ & $24 \%$ & $19 \%$ & $14 \%$ & $34 \%$ & $15 \%$ & $13 \%$ & $23 \%$ \\
\hline \multirow{3}{*}{2001} & $N$ & 191 & 29 & 136 & 140 & 91 & 619 & 154 & 250 & 1,610 \\
\hline & $\$ M M$ & 104,940 & 13,557 & 16,434 & 69,197 & 39,370 & 146,627 & 3,873 & 5,878 & 399,875 \\
\hline & $\% \mathrm{FV}$ & $5 \%$ & $7 \%$ & $14 \%$ & $19 \%$ & $11 \%$ & $31 \%$ & $16 \%$ & $14 \%$ & $20 \%$ \\
\hline \multirow{3}{*}{2002} & $N$ & 190 & 11 & 129 & 88 & 50 & 613 & 136 & 209 & 1,426 \\
\hline & $\$ M M$ & 82,772 & 8,030 & 16,256 & 24,446 & 17,299 & 145,998 & 4,320 & 3,012 & 302,134 \\
\hline & $\% F V$ & $4 \%$ & $6 \%$ & $11 \%$ & $20 \%$ & $10 \%$ & $29 \%$ & $12 \%$ & $11 \%$ & $18 \%$ \\
\hline \multirow{3}{*}{2003} & $\mathrm{~N}$ & 160 & 17 & 169 & 147 & 179 & 644 & 117 & 269 & 1,702 \\
\hline & \$MM & 80,685 & 10,165 & 18,484 & 44,040 & 42,627 & 154,405 & 2,574 & 4,296 & 357,275 \\
\hline & $\% \mathrm{FV}$ & $5 \%$ & $7 \%$ & $21 \%$ & $19 \%$ & $18 \%$ & $29 \%$ & $19 \%$ & $20 \%$ & $22 \%$ \\
\hline \multirow{3}{*}{ Total } & $\mathrm{N}$ & 1,820 & 201 & 1,642 & 1,017 & 597 & 5,609 & 1,156 & 1,377 & 13,419 \\
\hline & $\$ M M$ & 636,245 & 72,357 & 163,762 & 320,968 & 159,477 & $1,493,159$ & 30,686 & 25,601 & $2,902,255$ \\
\hline & $\% F V$ & $7 \%$ & $14 \%$ & $22 \%$ & $27 \%$ & $17 \%$ & $33 \%$ & $15 \%$ & $15 \%$ & $23 \%$ \\
\hline \multicolumn{2}{|c|}{$\% \mathrm{FV}$ (med) } & $3 \%$ & $9 \%$ & $15 \%$ & $16 \%$ & $13 \%$ & $22 \%$ & $9 \%$ & $9 \%$ & $13 \%$ \\
\hline
\end{tabular}




\section{Table 2A: Summary Statistics}

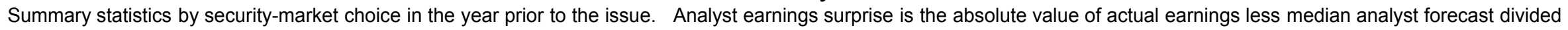

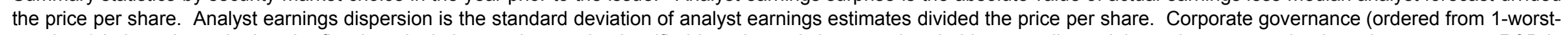

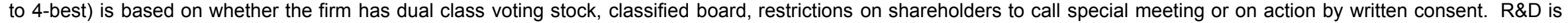

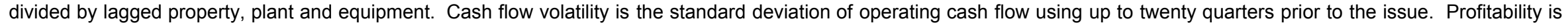

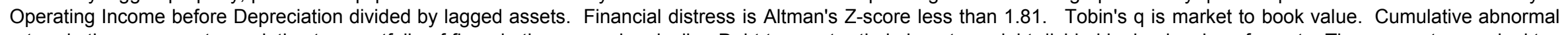

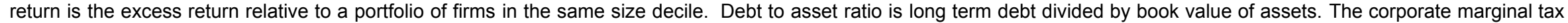
rate is computed as in Graham (1996). Firm value is market value of equity plus book values of preferred stock and total debt.

\begin{tabular}{|c|c|c|c|c|c|c|c|c|c|c|c|c|c|}
\hline Security/Mark & & $\begin{array}{l}\text { Analyst } \\
\text { Earnings } \\
\text { Surprise } \\
\end{array}$ & $\begin{array}{c}\text { Analyst } \\
\text { Earnings } \\
\text { Dispersion } \\
\end{array}$ & $\begin{array}{l}\text { Corporate } \\
\text { Governance }\end{array}$ & $\begin{array}{l}\text { Cash flow } \\
\text { Volatility }\end{array}$ & $\begin{array}{l}\text { R\&D / } \\
\text { lagged } \\
\text { PPE }\end{array}$ & $\begin{array}{c}\text { Profitability } \\
\text { (OCF/ lagged } \\
\text { assets) }\end{array}$ & $\begin{array}{l}\text { Financial } \\
\text { Distress }\end{array}$ & Tobin's $q$ & $\begin{array}{l}\text { Cumulative } \\
\text { Ab. Return } \\
\text { prior } 250 \text { days }\end{array}$ & $\begin{array}{l}\text { Debt } / \text { Asset } \\
\text { ratio }\end{array}$ & $\begin{array}{c}\text { Marginal } \\
\text { Tax Rate (\%) }\end{array}$ & $\begin{array}{l}\text { Firm Value } \\
\text { (\$ Millions) }\end{array}$ \\
\hline $\begin{array}{l}\text { Public } \\
\text { Debt }\end{array}$ & $\begin{array}{l}\text { Mean } \\
\text { Med } \\
\text { Stdev } \\
\mathrm{N}\end{array}$ & $\begin{array}{l}0.7 \% \\
0.3 \% \\
1.9 \% \\
1,756\end{array}$ & $\begin{array}{l}1.2 \% \\
0.2 \% \\
5.3 \% \\
1,717\end{array}$ & $\begin{array}{c}3.3 \\
3.0 \\
1.2 \\
1,712\end{array}$ & $\begin{array}{l}2.4 \% \\
1.9 \% \\
2.8 \% \\
1,820\end{array}$ & $\begin{array}{c}13.3 \% \\
2.5 \% \\
29.5 \% \\
1,820\end{array}$ & $\begin{array}{l}18.0 \% \\
17.4 \% \\
8.2 \% \\
1,820\end{array}$ & $\begin{array}{c}10.1 \% \\
0.0 \% \\
30.2 \% \\
1,820\end{array}$ & $\begin{array}{c}1.6 \\
1.3 \\
1.1 \\
1,820\end{array}$ & $\begin{array}{c}6.8 \% \\
1.4 \% \\
42.3 \% \\
1,820\end{array}$ & $\begin{array}{c}26.8 \% \\
25.2 \% \\
14.9 \% \\
1,820\end{array}$ & $\begin{array}{c}25.1 \% \\
35.0 \% \\
14.5 \% \\
1,705\end{array}$ & $\begin{array}{c}24,561 \\
7,841 \\
45,161 \\
1,820\end{array}$ \\
\hline $\begin{array}{c}\text { Public } \\
\text { Convertibles }\end{array}$ & $\begin{array}{l}\text { Mean } \\
\text { Med } \\
\text { Stdev } \\
\mathrm{N}\end{array}$ & $\begin{array}{c}1.8 \% \\
0.6 \% \\
4.5 \% \\
187\end{array}$ & $\begin{array}{c}1.9 \% \\
0.4 \% \\
4.7 \% \\
180\end{array}$ & $\begin{array}{r}3.2 \\
3.0 \\
1.3 \\
175\end{array}$ & $\begin{array}{c}4.2 \% \\
2.4 \% \\
5.5 \% \\
201\end{array}$ & $\begin{array}{c}32.6 \% \\
0.0 \% \\
102.2 \% \\
201\end{array}$ & $\begin{array}{c}12.6 \% \\
14.2 \% \\
18.9 \% \\
201\end{array}$ & $\begin{array}{c}21.4 \% \\
0.0 \% \\
41.1 \% \\
201\end{array}$ & $\begin{array}{l}2.0 \\
1.4 \\
2.0 \\
201\end{array}$ & $\begin{array}{c}43.4 \% \\
18.0 \% \\
101.4 \% \\
201\end{array}$ & $\begin{array}{c}27.5 \% \\
27.0 \% \\
17.4 \% \\
201\end{array}$ & $\begin{array}{c}18.3 \% \\
17.7 \% \\
16.0 \% \\
180\end{array}$ & $\begin{array}{c}8,152 \\
2,346 \\
19,600 \\
201\end{array}$ \\
\hline $\begin{array}{l}\text { Public } \\
\text { Equity }\end{array}$ & $\begin{array}{l}\text { Mean } \\
\text { Med } \\
\text { Stdev } \\
\mathrm{N}\end{array}$ & $\begin{array}{l}1.9 \% \\
0.6 \% \\
5.4 \% \\
1,491\end{array}$ & $\begin{array}{l}1.1 \% \\
0.3 \% \\
3.3 \% \\
1,326\end{array}$ & $\begin{array}{c}3.4 \\
3.0 \\
1.2 \\
1,167\end{array}$ & $\begin{array}{c}8.0 \% \\
4.5 \% \\
13.4 \% \\
1,642\end{array}$ & $\begin{array}{c}110.4 \% \\
4.3 \% \\
233.5 \% \\
1,642\end{array}$ & $\begin{array}{c}11.1 \% \\
16.0 \% \\
26.8 \% \\
1,642\end{array}$ & $\begin{array}{c}13.1 \% \\
0.0 \% \\
33.7 \% \\
1,642\end{array}$ & $\begin{array}{c}2.7 \\
1.8 \\
2.3 \\
1,642\end{array}$ & $\begin{array}{c}83.5 \% \\
44.7 \% \\
134.1 \% \\
1,642\end{array}$ & $\begin{array}{c}22.4 \% \\
17.6 \% \\
22.2 \% \\
1,642\end{array}$ & $\begin{array}{c}18.1 \% \\
21.2 \% \\
16.1 \% \\
1,337\end{array}$ & $\begin{array}{c}1,449 \\
367 \\
5,358 \\
1,642\end{array}$ \\
\hline $\begin{array}{c}\text { 144-A } \\
\text { Convertibles }\end{array}$ & $\begin{array}{c}\text { Mean } \\
\text { Med } \\
\text { Stdev } \\
\mathrm{N}\end{array}$ & $\begin{array}{c}2.9 \% \\
0.7 \% \\
10.0 \% \\
930\end{array}$ & $\begin{array}{c}2.0 \% \\
0.5 \% \\
5.9 \% \\
851\end{array}$ & $\begin{array}{r}3.2 \\
3.0 \\
1.2 \\
814\end{array}$ & $\begin{array}{l}3.9 \% \\
2.5 \% \\
4.9 \% \\
1,017\end{array}$ & $\begin{array}{c}12.9 \% \\
0.0 \% \\
44.1 \% \\
1,017\end{array}$ & $\begin{array}{c}15.3 \% \\
14.6 \% \\
14.0 \% \\
1,017\end{array}$ & $\begin{array}{c}30.9 \% \\
0.0 \% \\
46.2 \% \\
1,017\end{array}$ & $\begin{array}{c}1.4 \\
1.1 \\
1.1 \\
1,017\end{array}$ & $\begin{array}{c}18.8 \% \\
4.0 \% \\
75.2 \% \\
1,017\end{array}$ & $\begin{array}{c}37.6 \% \\
35.8 \% \\
22.0 \% \\
1,017\end{array}$ & $\begin{array}{c}17.9 \% \\
18.3 \% \\
15.8 \% \\
915\end{array}$ & $\begin{array}{c}5,340 \\
1,162 \\
17,638 \\
1,017\end{array}$ \\
\hline $\begin{array}{l}144-A \\
\text { Debt }\end{array}$ & $\begin{array}{c}\text { Mean } \\
\text { Med } \\
\text { Stdev } \\
\mathrm{N}\end{array}$ & $\begin{array}{c}2.4 \% \\
0.5 \% \\
9.2 \% \\
571\end{array}$ & $\begin{array}{c}1.7 \% \\
0.3 \% \\
4.7 \% \\
551\end{array}$ & $\begin{array}{c}3.5 \\
3.0 \\
1.2 \\
524\end{array}$ & $\begin{array}{c}6.2 \% \\
3.7 \% \\
10.6 \% \\
597\end{array}$ & $\begin{array}{c}100.6 \% \\
12.2 \% \\
216.9 \% \\
597\end{array}$ & $\begin{array}{c}10.6 \% \\
12.2 \% \\
21.2 \% \\
597\end{array}$ & $\begin{array}{c}17.8 \% \\
0.0 \% \\
38.2 \% \\
597\end{array}$ & $\begin{array}{l}2.4 \\
1.6 \\
2.4 \\
597\end{array}$ & $\begin{array}{c}50.9 \% \\
17.5 \% \\
152.9 \% \\
597\end{array}$ & $\begin{array}{c}23.5 \% \\
20.3 \% \\
21.7 \% \\
597\end{array}$ & $\begin{array}{c}15.1 \% \\
3.7 \% \\
15.8 \% \\
502\end{array}$ & $\begin{array}{c}4,258 \\
1,255 \\
9,413 \\
597\end{array}$ \\
\hline $\begin{array}{c}\text { Private } \\
\text { Debt }\end{array}$ & $\begin{array}{c}\text { Mean } \\
\text { Med } \\
\text { Stdev } \\
\mathrm{N}\end{array}$ & $\begin{array}{c}3.6 \% \\
0.7 \% \\
11.7 \% \\
4,784\end{array}$ & $\begin{array}{l}1.7 \% \\
0.4 \% \\
5.4 \% \\
4,166\end{array}$ & $\begin{array}{c}3.3 \\
3.0 \\
1.2 \\
4,058\end{array}$ & $\begin{array}{l}4.8 \% \\
3.1 \% \\
7.1 \% \\
5,609\end{array}$ & $\begin{array}{c}29.5 \% \\
0.9 \% \\
89.8 \% \\
5,609\end{array}$ & $\begin{array}{c}15.5 \% \\
15.1 \% \\
14.8 \% \\
5,609\end{array}$ & $\begin{array}{c}14.0 \% \\
0.0 \% \\
34.7 \% \\
5,609\end{array}$ & $\begin{array}{c}1.5 \\
1.1 \\
1.2 \\
5,609\end{array}$ & $\begin{array}{c}4.9 \% \\
-5.9 \% \\
66.5 \% \\
5,609\end{array}$ & $\begin{array}{c}23.6 \% \\
20.7 \% \\
19.8 \% \\
5,609\end{array}$ & $\begin{array}{c}20.5 \% \\
30.9 \% \\
15.6 \% \\
4,993\end{array}$ & $\begin{array}{c}2,777 \\
468 \\
10,934 \\
5,609\end{array}$ \\
\hline $\begin{array}{c}\text { Private } \\
\text { Convertibles }\end{array}$ & $\begin{array}{c}\text { Mean } \\
\text { Med } \\
\text { Stdev } \\
\mathrm{N}\end{array}$ & $\begin{array}{c}16.2 \% \\
5.6 \% \\
27.4 \% \\
638\end{array}$ & $\begin{array}{c}5.8 \% \\
1.8 \% \\
10.5 \% \\
428\end{array}$ & $\begin{array}{l}3.8 \\
4.0 \\
1.2 \\
905\end{array}$ & $\begin{array}{c}17.0 \% \\
11.5 \% \\
21.3 \% \\
1,156\end{array}$ & $\begin{array}{c}161.9 \% \\
56.7 \% \\
255.0 \% \\
1,156\end{array}$ & $\begin{array}{c}-22.0 \% \\
-17.3 \% \\
34.4 \% \\
1,156\end{array}$ & $\begin{array}{c}32.9 \% \\
0.0 \% \\
47.0 \% \\
1,156\end{array}$ & $\begin{array}{c}2.7 \\
1.7 \\
2.7 \\
1,156\end{array}$ & $\begin{array}{c}1.8 \% \\
-30.4 \% \\
131.4 \% \\
1,156\end{array}$ & $\begin{array}{c}16.5 \% \\
7.5 \% \\
21.3 \% \\
1,156\end{array}$ & $\begin{array}{c}4.5 \% \\
0.7 \% \\
10.0 \% \\
976\end{array}$ & $\begin{array}{c}374 \\
65 \\
1,752 \\
1,156\end{array}$ \\
\hline $\begin{array}{l}\text { Private } \\
\text { Equity }\end{array}$ & $\begin{array}{c}\text { Mean } \\
\text { Med } \\
\text { Stdev } \\
\mathrm{N} \\
\end{array}$ & $\begin{array}{c}13.4 \% \\
3.9 \% \\
24.8 \% \\
852 \\
\end{array}$ & $\begin{array}{c}5.3 \% \\
1.5 \% \\
10.3 \% \\
574 \\
\end{array}$ & $\begin{array}{c}3.8 \\
4.0 \\
1.2 \\
1,168 \\
\end{array}$ & $\begin{array}{c}17.6 \% \\
11.3 \% \\
22.6 \% \\
1,377 \\
\end{array}$ & $\begin{array}{c}244.7 \% \\
111.6 \% \\
333.5 \% \\
1,377 \\
\end{array}$ & $\begin{array}{c}-25.1 \% \\
-21.4 \% \\
35.8 \% \\
1,377 \\
\end{array}$ & $\begin{array}{c}26.2 \% \\
0.0 \% \\
44.0 \% \\
1,377 \\
\end{array}$ & $\begin{array}{c}3.0 \\
2.1 \\
2.8 \\
1,377 \\
\end{array}$ & $\begin{array}{c}24.5 \% \\
-10.6 \% \\
131.2 \% \\
1,377 \\
\end{array}$ & $\begin{array}{c}12.3 \% \\
3.6 \% \\
18.6 \% \\
1,377 \\
\end{array}$ & $\begin{array}{l}4.5 \% \\
0.8 \% \\
9.8 \% \\
1,162 \\
\end{array}$ & $\begin{array}{c}486 \\
79 \\
3,234 \\
1,377 \\
\end{array}$ \\
\hline Total & $\begin{array}{c}\text { Mean } \\
\text { Med } \\
\text { Stdev } \\
\mathrm{N}\end{array}$ & $\begin{array}{c}4.2 \% \\
0.7 \% \\
13.5 \% \\
11,209 \\
\end{array}$ & $\begin{array}{l}1.9 \% \\
0.4 \% \\
6.0 \% \\
9,793 \\
\end{array}$ & $\begin{array}{c}3.4 \\
3.0 \\
1.2 \\
10,523 \\
\end{array}$ & $\begin{array}{c}7.2 \% \\
3.5 \% \\
13.0 \% \\
13,419 \\
\end{array}$ & $\begin{array}{c}72.7 \% \\
3.7 \% \\
187.2 \% \\
13,419 \\
\end{array}$ & $\begin{array}{c}7.6 \% \\
13.6 \% \\
26.4 \% \\
13,419 \\
\end{array}$ & $\begin{array}{c}17.8 \% \\
0.0 \% \\
38.3 \% \\
13,419 \\
\end{array}$ & $\begin{array}{c}1.9 \\
1.3 \\
1.9 \\
13,419 \\
\end{array}$ & $\begin{array}{c}20.2 \% \\
0.9 \% \\
99.2 \% \\
13,419 \\
\end{array}$ & $\begin{array}{l}23.2 \% \\
20.0 \% \\
20.6 \% \\
13,419 \\
\end{array}$ & $\begin{array}{l}17.5 \% \\
15.1 \% \\
16.1 \% \\
11,770 \\
\end{array}$ & $\begin{array}{c}5,468 \\
520 \\
20,590 \\
13,419 \\
\end{array}$ \\
\hline
\end{tabular}


Table 2B

Summary Statistics: Tests of Differences in Markets

The first row presents the t-statistics for the equality of means of each variable in Table 2A by market, and the second row presents the Mann-Whitney two-sample statistics.

\begin{tabular}{|c|c|c|c|c|c|c|c|c|c|c|c|c|}
\hline $\begin{array}{l}\text { Statistics for } \\
\text { difference in Market }\end{array}$ & $\begin{array}{l}\text { Analyst } \\
\text { Earnings } \\
\text { Surprise }\end{array}$ & $\begin{array}{c}\text { Analyst } \\
\text { Earnings } \\
\text { Dispersion }\end{array}$ & $\begin{array}{l}\text { Corporate } \\
\text { Governance }\end{array}$ & $\begin{array}{l}\text { Cash flow } \\
\text { Volatility }\end{array}$ & $\begin{array}{l}\text { R\&D / } \\
\text { lagged } \\
\text { PPE }\end{array}$ & $\begin{array}{c}\text { Profitability } \\
\text { (OCF/lagged } \\
\text { assets) }\end{array}$ & $\begin{array}{l}\text { Financial } \\
\text { Distress }\end{array}$ & Tobin's $q$ & $\begin{array}{l}\text { Cumulative } \\
\text { Ab. Return } \\
\text { prior } 250 \text { days }\end{array}$ & $\begin{array}{l}\text { Debt/ } \\
\text { Assets }\end{array}$ & $\begin{array}{l}\text { Marginal } \\
\text { Tax Rate }\end{array}$ & $\begin{array}{l}\text { Firm Value } \\
\text { (\$ Millions) }\end{array}$ \\
\hline \multicolumn{13}{|l|}{ Debt } \\
\hline$\overline{\text { Private Debt }}$ & $10.3^{a}$ & $2.9^{a}$ & $2.3^{b}$ & $14.0^{a}$ & $7.6^{\mathrm{a}}$ & $-6.9^{a}$ & $4.3^{a}$ & $-3.3^{a}$ & -1.1 & $-6.4^{a}$ & $-10.5^{a}$ & $-33.2^{a}$ \\
\hline vs. Public Debt & $22.0^{a}$ & $13.0^{\mathrm{a}}$ & $1.8^{\mathrm{c}}$ & $25.2^{a}$ & $-2.0^{b}$ & $-9.3^{a}$ & $4.3^{\mathrm{a}}$ & $-8.6^{a}$ & $-7.6^{a}$ & $-10.1^{a}$ & $-11.1^{a}$ & $-49.2^{a}$ \\
\hline Private Debt & $1.5^{b}$ & -1.7 & $2.6^{a}$ & $4.2^{\mathrm{a}}$ & $5.8^{a}$ & 0.5 & $-13.5^{a}$ & 1.2 & $-6.0^{a}$ & $-20.4^{a}$ & $4.6^{\mathrm{a}}$ & $-6.2^{a}$ \\
\hline vs. $144-A$ Debt & 0.7 & $-3.9^{a}$ & $2.7^{\mathrm{a}}$ & $7.5^{\mathrm{a}}$ & $5.5^{\mathrm{a}}$ & 1.2 & $-13.3^{a}$ & -0.1 & $-6.9^{a}$ & $-19.3^{a}$ & $4.2^{\mathrm{a}}$ & $-16.9^{a}$ \\
\hline 144-A Debt & $9.1^{\mathrm{a}}$ & $3.5^{\mathrm{a}}$ & -0.8 & $9.8^{\mathrm{a}}$ & -0.3 & $-6.6^{a}$ & $14.4^{\mathrm{a}}$ & $-3.6^{a}$ & $5.5^{\mathrm{a}}$ & $15.5^{\mathrm{a}}$ & $-11.6^{a}$ & $-13.0^{a}$ \\
\hline $\begin{array}{l}\text { vs. Public Debt } \\
\text { Convertibles }\end{array}$ & $15.0^{\mathrm{a}}$ & $12.4^{\mathrm{a}}$ & -1.3 & $11.1^{\mathrm{a}}$ & $-6.9^{a}$ & $-8.0^{a}$ & $13.9^{a}$ & $-6.4^{a}$ & $1.8^{a}$ & $13.3^{a}$ & $-10.7^{a}$ & $-27.3^{a}$ \\
\hline Private Convertibles & $7.1^{\mathrm{a}}$ & $4.9^{a}$ & $5.8^{a}$ & $8.4^{a}$ & $7.1^{\mathrm{a}}$ & $-13.9^{a}$ & $3.3^{a}$ & $3.2^{a}$ & $-4.3^{a}$ & $-6.9^{a}$ & $-15.3^{a}$ & $-13.2^{a}$ \\
\hline vs. Public Convertibles & $14.3^{a}$ & $9.0^{\mathrm{a}}$ & $5.7^{\mathrm{a}}$ & $16.7^{\mathrm{a}}$ & $9.8^{a}$ & $-15.8^{a}$ & $3.2^{\mathrm{a}}$ & $3.1^{\mathrm{a}}$ & $-9.7^{a}$ & $-9.2^{a}$ & $-11.3^{a}$ & $-18.9^{a}$ \\
\hline Private Convertibles & $11.4^{\mathrm{a}}$ & $8.3^{a}$ & $4.9^{a}$ & $11.6^{a}$ & $5.0^{\mathrm{a}}$ & $-21.2^{a}$ & $6.8^{a}$ & $2.3^{b}$ & $-7.0^{a}$ & $-6.5^{a}$ & $-15.7^{a}$ & $-13.6^{a}$ \\
\hline vs. $144-A$ Convertibles & $20.6^{a}$ & $13.6^{\mathrm{a}}$ & $4.8^{a}$ & $21.1^{\mathrm{a}}$ & $6.2^{\mathrm{a}}$ & $-21.5^{a}$ & $6.7^{\mathrm{a}}$ & $1.8^{\mathrm{c}}$ & $-14.6^{a}$ & $-7.8^{a}$ & $-14.9^{a}$ & $-29.7^{a}$ \\
\hline 144-A Convertibles & 0.9 & -0.5 & $2.4^{\mathrm{b}}$ & $2.6^{a}$ & $4.3^{a}$ & -1.2 & -1.1 & 1.8 & 0.6 & $-2.3^{b}$ & $-2.4^{b}$ & $-3.7^{a}$ \\
\hline $\begin{array}{l}\text { Public Convertibles } \\
\text { Equity }\end{array}$ & -0.2 & -0.8 & $2.7^{\mathrm{a}}$ & $5.5^{\mathrm{a}}$ & $6.1^{\mathrm{a}}$ & $-1.9^{c}$ & -1.1 & $2.1^{\mathrm{c}}$ & 0.0 & $-3.7^{a}$ & $-1.7^{c}$ & -3.2 \\
\hline Private Equity & $17.2^{\mathrm{a}}$ & $13.2^{\mathrm{a}}$ & $7.8^{a}$ & $14.4^{\mathrm{a}}$ & $13.0^{\mathrm{a}}$ & $-31.7^{a}$ & $9.3^{a}$ & $3.9^{a}$ & $-12.2^{a}$ & $-13.4^{a}$ & $-25.2^{a}$ & $-5.8^{a}$ \\
\hline vs. Public Equity & $23.7^{\mathrm{a}}$ & $17.4^{a}$ & $7.6^{\mathrm{a}}$ & $23.8^{a}$ & $18.1^{\mathrm{a}}$ & $-30.7^{a}$ & $9.1^{\mathrm{a}}$ & $2.1^{a}$ & $-21.1^{a}$ & $-13.9^{a}$ & $-21.3^{a}$ & $-26.6^{a}$ \\
\hline
\end{tabular}

a, b,c- represent significance levels of one, five, and ten percent. 
Table 3

Market Reaction to Security Issuance

Table presents regression of 10 trading-day cumulative abnormal returns around security issues on the variables defined in Table 2A. The forecast error variable appears interacted with the public and private market dummy. All explanatory variables (except the dummy variables) have been normalized by their standard deviation. t-statistics are denoted below the coefficients. a,b,c - Significantly different from zero at the one-percent (five, ten) level of significance. We include industry fixed effects (Fama and French 17 industry categories) in all regressions.

Equity Issues

Public Market
Private Market
Forecast error ${ }^{*}$ Public Market
Forecast error ${ }^{*}$ Private Market

Forecast error * Private Market

Corporate Governance

Cash Flow Volatility

R\&D / lagged PPE

Profitability

(Operating cash flow/ lagged assets)

Financial Distress

(Z-score < 1.81)

Tobin's $q$

Cumulative Ab. Stock Return (250 prior days)

Debt/Asset Ratio (Industry Adjusted)

Log Size

(firm value)

Cumulative Market Return

(Prior year)

Marginal Tax Rate

Number of observations

F-value

Adjusted $\mathrm{R}^{2}$
(1)

(2)

$-1.62 \% b$
-2.54

$2.77 \%$ b

2.16

$-1.60 \% c$ $-1.82$

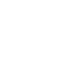

$0.50 \%$

0.87

$1.76 \%$

1.29

$-3.60 \%$

$-1.25$

$0.96 \%{ }^{c}$

1.80

$0.06 \%$

0.11

$0.16 \%$

0.28

$0.26 \%$

0.50

$0.49 \%$

0.94

$0.12 \%$

0.20

$-0.40 \%$

$-0.60$

$-1.53 \%$ b

$-2.13$

$3.43 \%{ }^{c}$

1.90

$2.98 \%{ }^{c}$

$-0.18 \%$

$-0.30$

1.66

$-0.27 \%$

$-0.48$

$-1.69 \%^{\mathrm{a}} \quad-1.38 \%^{\mathrm{a}}$

$-3.66$

$-2.81$

$-0.40 \%$

$-0.78$

$-0.59 \%$

$-1.19$

$-0.23 \%$

$-0.26$

$0.74 \%$

0.90

$0.84 \%$

1.20

$0.77 \%$

1.13

$-0.55 \%$

$-0.91$

$-0.07 \%$

$-0.11$

$1,959 \quad 1,593$

5.85

4.01

$4.40 \%$
Convertible Issues

(3)

$-2.31 \%$ a

(4)

$-2.53 \%$ a

$-2.65$

$-0.35 \%$

$-0.24$

$-2.65$

Debt Issues

(5)

$-0.89 \%$ b

$-1.97$

(6)

$-0.95 \%$

$-1.83$

$-0.07 \%$

$-0.02 \%$

$1.83 \%$

1.14

$-0.19$

$-0.06$

$-3.68 \%{ }^{a}$

$-4.15$

$-0.22 \%$

$-0.20$

$-0.81 \%$

$-1.10$

$-0.07 \%$

$0.07 \%$

$-0.10$

0.09

$-0.19 \%$

$-0.21$

$-0.68 \%$

$-0.69$

$0.81 \%$

1.09

$1.12 \%$

1.25

$-0.55 \%$

$-1.43 \%$

$-0.60$

$-1.33$

$6.21 \%{ }^{a}$

2.90

$4.08 \%$

1.63

$0.57 \%$

0.76

$0.06 \%$

0.08

$-0.79 \%$

$-1.05$

$0.70 \%$

0.77

$-0.56 \%$

$-0.78$

$-1.65 \%$ b

$-2.26$

$-1.30 \%$

$-1.18$

$-0.90 \%$

$-0.77$

$-1.10 \%$

$-1.63$

$-0.54 \%$

$-0.69$

$0.35 \%$

0.46

$-0.02 \%$

$-0.02$

102

1,374
2.47

2.74

1,102
2.94

$3.38 \%$ 


\section{Table 4}

\section{Choice of Security: Debt versus Equity}

\section{Debt and Equity Aggregated Across Markets}

Table presents coefficient estimates from simple binomial logit regressions combining security issues into equity and debt groups with no indication of choice of market, nor choice of convertible securities. The dependent variable equals one for equity issues and zero for debt issues. All firm-specific variables are lagged. All market-specific variables represent three months prior to the security issuance. For the measure of asymmetric information, column 1 uses analyst earnings dispersion calculated as the standard deviation of the analyst forecasts divided by price per share. Column 2 uses the earnings forecast surprise calculated as the absolute value of the median forecast less the actual earnings divided by the price per share. All explanatory variables (except predicted financial need) are as defined in Table 2A and they have all been normalized by their standard deviation (except the dummy variable financial distress). Predicted financial need (internal funding deficit) is the instrumented amount of capital expenditures plus increase in net working capital less operating income before depreciation. (Robust Z-statistics are presented in parentheses). Industry fixed effects (Fama-French 17 industry categories) are included.

\begin{tabular}{|c|c|c|}
\hline Explanatory Variables & $\begin{array}{l}\text { Earnings } \\
\text { Forecast } \\
\text { Surprise }\end{array}$ & $\begin{array}{r}\text { Analyst } \\
\text { Earnings } \\
\text { Dispersion }\end{array}$ \\
\hline Measures of Asymmetric Information & $\begin{array}{l}0.001 \\
(.050)\end{array}$ & $\begin{array}{l}-0.028 \\
(-.840)\end{array}$ \\
\hline \multicolumn{3}{|l|}{ Risk Measure } \\
\hline Cash Flow Volatility & $\begin{array}{l}0.130^{\mathrm{a}} \\
(2.510)\end{array}$ & $\begin{array}{l}0.183^{a} \\
(2.870)\end{array}$ \\
\hline \multicolumn{3}{|l|}{ Investment Opportunities Measures } \\
\hline R\&D / lagged PPE & $\begin{array}{l}0.108^{b} \\
(2.380)\end{array}$ & $\begin{array}{l}0.093^{\mathrm{c}} \\
(1.870)\end{array}$ \\
\hline Tobin's $q$ & $\begin{array}{c}0.384^{\mathrm{a}} \\
(7.830)\end{array}$ & $\begin{array}{l}0.359^{a} \\
(6.910)\end{array}$ \\
\hline $\begin{array}{l}\text { Profitability } \\
\text { (Operating cash flow/ lagged assets) }\end{array}$ & $\begin{array}{l}-0.361^{a} \\
(-6.860)\end{array}$ & $\begin{array}{l}-0.372^{a} \\
(-6.170)\end{array}$ \\
\hline $\begin{array}{l}\text { Financial Distress } \\
(Z \text {-score }<1.81)\end{array}$ & $\begin{array}{l}0.219^{b} \\
(2.140)\end{array}$ & $\begin{array}{l}0.225^{b} \\
(2.030)\end{array}$ \\
\hline Corporate Governance & $\begin{array}{l}0.026 \\
(.760)\end{array}$ & $\begin{array}{l}0.016 \\
(.460)\end{array}$ \\
\hline \multicolumn{3}{|l|}{ Size Measures } \\
\hline $\begin{array}{l}\text { Log Firm Size } \\
\text { (firm value) }\end{array}$ & $\begin{array}{r}-0.888^{a} \\
(-16.090)\end{array}$ & $\begin{array}{r}-0.924^{a} \\
(-14.520)\end{array}$ \\
\hline Predicted Financial Need & $\begin{array}{r}0.106 \\
(1.350)\end{array}$ & $\begin{array}{l}0.079 \\
(.880)\end{array}$ \\
\hline \multicolumn{3}{|l|}{ Debt and Taxes } \\
\hline $\begin{array}{l}\text { Debt/Asset Ratio } \\
\text { (Industry Adjusted) }\end{array}$ & $\begin{array}{l}0.091^{\mathrm{a}} \\
(2.550)\end{array}$ & $\begin{array}{l}0.109^{\mathrm{a}} \\
(2.810)\end{array}$ \\
\hline Marginal Tax Rate & $\begin{array}{l}-0.153^{a} \\
(-3.710)\end{array}$ & $\begin{array}{l}-0.126^{a} \\
(-2.900)\end{array}$ \\
\hline \multicolumn{3}{|l|}{ Market Timing \& Market Characteristics } \\
\hline $\begin{array}{l}\text { Cumulative Abnormal Stock Return } \\
\text { (250 prior days) }\end{array}$ & $\begin{array}{l}0.288^{a} \\
(7.250)\end{array}$ & $\begin{array}{l}0.301^{\mathrm{a}} \\
(6.710)\end{array}$ \\
\hline $\begin{array}{l}\text { Cumulative Market Return } \\
\text { (Prior year) }\end{array}$ & $\begin{array}{l}0.093^{a} \\
(2.780)\end{array}$ & $\begin{array}{r}0.047 \\
(1.250)\end{array}$ \\
\hline Aaa Bond Rate & $\begin{array}{l}0.187^{\mathrm{a}} \\
(4.880)\end{array}$ & $\begin{array}{l}0.234^{\mathrm{a}} \\
(5.620)\end{array}$ \\
\hline Credit Spread: Baa - Aaa & $\begin{array}{c}0.204^{\mathrm{a}} \\
(4.910)\end{array}$ & $\begin{array}{l}0.212^{a} \\
(4.720) \\
\end{array}$ \\
\hline $\begin{array}{l}\text { Number of issues } \\
\text { Pseudo R-squared }\end{array}$ & $\begin{array}{r}8,346 \\
27.7 \%\end{array}$ & $\begin{array}{r}7,536 \\
25.6 \%\end{array}$ \\
\hline
\end{tabular}

a,b,c - Significantly different from zero at the one-percent (five, ten) level of significance. 
Table 5

\section{Choice of Security Issuance in Public and Private Markets}

Table presents coefficient estimates from a nested logit regression testing the impact of asymmetric information and risk on firm public and private security choice by public firms. First stage is the decision of security type with coefficients representing tendency relative to debt. Second stage is the choice of market conditional on security type, with coefficients representing tendency versus public issuance. All firm-specific variables are lagged. Explanatory variables are as defined in Table $2 \mathrm{~A}$ and they have all been normalized by their standard deviation (except the dummy variable financial distress). Analyst earnings surprise is the absolute value of actual earnings less median analyst forecast divided the price per share. (Robust Z-statistics are presented in parentheses.) Predicted financial need (internal funding deficit) is the instrumented amount of capital expenditures plus increase in net working capital less operating income before depreciation. Chisquared statistic for test of overall significance is 11642 ( $p$-value .001). Sample is 8346 security issues. Industry fixed effects are included for each security type.

\section{Explanatory Variables}

Asymmetric Information Measure

Analyst Earnings Surprise

\section{Risk Measure}

Cash Flow Volatility

$\underline{\text { Investment Opportunities Measures }}$

R\&D / lagged PPE

Tobin's $q$

Profitability

(Operating cash flow/ lagged assets)

Financial Distress

(Z-score<1.81)

Corporate Governance

\begin{tabular}{l}
$\frac{\text { Size Measures }}{\text { Log Size }}$ \\
(Firm Value) \\
Predicted Financial Need \\
Debt and Taxes \\
\hline Debt/Asset Ratio \\
(Industry Adjusted) \\
Marginal Tax Rate
\end{tabular}

Market Timing \& Market Characteristics

Cumulative Abnormal Stock Return

(250 prior days)

Cumulative Market Return

(Prior year)

Aaa Bond Rate

Credit Spread: Baa - Aaa
First Stage

Security Decision Convertibles Equity (vs. Debt)

\begin{tabular}{|c|c|c|c|c|}
\hline $\begin{array}{l}0.007 \\
(.080)\end{array}$ & $\begin{array}{c}-0.655^{a} \\
(-3.440)\end{array}$ & $\begin{array}{c}1.060^{\mathrm{a}} \\
(6.520)^{2}\end{array}$ & $\begin{array}{c}0.388^{a} \\
(3.670)\end{array}$ & $\begin{array}{c}0.201 \\
(3.300)\end{array}$ \\
\hline $\begin{array}{c}0.419^{a} \\
(3.630)\end{array}$ & $\begin{array}{c}0.491 \\
(4.440)\end{array}$ & $\begin{array}{l}-0.005 \\
(-.120)\end{array}$ & $\begin{array}{r}0.137 \\
(1.480)\end{array}$ & $\begin{array}{c}0.218^{b} \\
(1.970)\end{array}$ \\
\hline $\begin{array}{c}0.639^{a} \\
(4.200)\end{array}$ & $\begin{array}{c}0.651^{\mathrm{a}} \\
(4.410)^{-}\end{array}$ & $\begin{array}{l}-0.102^{b} \\
(-2.110)\end{array}$ & $\begin{array}{l}-0.227^{\mathrm{a}} \\
(-2.950)\end{array}$ & $\begin{array}{c}0.415^{a} \\
(2.720)\end{array}$ \\
\hline $\begin{array}{c}0.817^{a} \\
(7.570)\end{array}$ & $\begin{array}{l}0.921^{a} \\
(8.290)\end{array}$ & $\begin{array}{c}0.179^{a} \\
(3.170)\end{array}$ & $\begin{array}{c}0.311^{\mathrm{a}} \\
(3.910)\end{array}$ & $\begin{array}{c}0.523^{a} \\
(6.820)\end{array}$ \\
\hline $\begin{array}{l}-0.739^{a} \\
(-7.330)\end{array}$ & $\begin{array}{c}-0.617^{a} \\
(-6.440)\end{array}$ & $\begin{array}{c}-0.517^{a} \\
(-7.160)\end{array}$ & $\begin{array}{l}-0.297^{\mathrm{a}} \\
(-2.800)\end{array}$ & $\begin{array}{c}-0.150^{\mathrm{c}} \\
(-1.750)\end{array}$ \\
\hline $\begin{array}{l}-0.021 \\
(-.130)\end{array}$ & $\begin{array}{r}-0.164 \\
(-1.070)\end{array}$ & $\begin{array}{r}0.225 \\
(1.140)\end{array}$ & $\begin{array}{r}0.322 \\
(1.290)\end{array}$ & $\begin{array}{c}-0.439^{\mathrm{a}} \\
(-4.230)^{2}\end{array}$ \\
\hline $\begin{array}{r}0.074 \\
(1.560)\end{array}$ & $\begin{array}{l}0.006 \\
(.150)\end{array}$ & $\begin{array}{c}0.176{ }^{a} \\
(2.720)\end{array}$ & $\begin{array}{l}0.023 \\
(.270)\end{array}$ & $\begin{array}{l}0.030 \\
(.910)\end{array}$ \\
\hline $\begin{array}{c}-0.4466^{b} \\
(-2.350)\end{array}$ & $\begin{array}{c}-1.547^{a} \\
(-6.690)\end{array}$ & $\begin{array}{c}-1.044^{\mathrm{a}} \\
(-7.940)\end{array}$ & $\begin{array}{r}-2.846^{\mathrm{a}} \\
(-13.710)\end{array}$ & $\begin{array}{r}-1.419^{a} \\
(-21.750)\end{array}$ \\
\hline $\begin{array}{c}0.172 \\
(3.660)\end{array}$ & $\begin{array}{c}0.240 \\
(3.020)\end{array}$ & $\begin{array}{c}-1.087^{\mathrm{a}} \\
(-4.940)\end{array}$ & $\begin{array}{c}-0.887^{\mathrm{a}} \\
(-2.980)\end{array}$ & $\begin{array}{l}0.001 \\
(.030)\end{array}$ \\
\hline $\begin{array}{l}-0.009 \\
(-.190)\end{array}$ & $\begin{array}{c}0.138 \\
(2.950)\end{array}$ & $\begin{array}{r}-0.084 \\
(-1.260)\end{array}$ & $\begin{array}{c}0.204^{\mathrm{b}} \\
(2.340)\end{array}$ & $\begin{array}{r}-0.055 \\
(-1.490)\end{array}$ \\
\hline $\begin{array}{c}-0.166^{a} \\
(-3.030)\end{array}$ & $\begin{array}{l}-0.013 \\
(-.260)\end{array}$ & $\begin{array}{c}-0.408^{\mathrm{a}} \\
(-4.530)\end{array}$ & 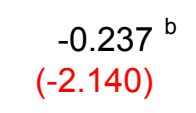 & $\begin{array}{l}0.024 \\
(.650)\end{array}$ \\
\hline $\begin{array}{c}0.323^{\mathrm{a}} \\
(4.570)\end{array}$ & $\begin{array}{c}0.423^{a} \\
(5.780)\end{array}$ & $\begin{array}{c}-0.394^{\mathrm{a}} \\
(-7.200)\end{array}$ & $\begin{array}{c}-0.6400^{\mathrm{a}} \\
(-7.300)^{2}\end{array}$ & $\begin{array}{c}-0.307^{a} \\
(-5.720)\end{array}$ \\
\hline $\begin{array}{l}0.042 \\
(.790)\end{array}$ & $\begin{array}{c}0.115^{b} \\
(2.320)\end{array}$ & $\begin{array}{l}-0.037 \\
(-.570)\end{array}$ & $\begin{array}{c}-0.193^{b} \\
(-2.080)\end{array}$ & $\begin{array}{r}-0.065^{c} \\
(-1.680)\end{array}$ \\
\hline $\begin{array}{c}-0.141^{b} \\
(-2.070)\end{array}$ & $\begin{array}{c}0.307^{\mathrm{a}} \\
(4.100)\end{array}$ & $\begin{array}{r}0.113 \\
(1.430)\end{array}$ & $\begin{array}{c}0.837^{\mathrm{a}} \\
(7.080)\end{array}$ & $\begin{array}{c}0.296 \\
(7.190)\end{array}$ \\
\hline $\begin{array}{c}0.131^{c} \\
(1.650)\end{array}$ & $\begin{array}{c}0.337^{a} \\
(4.360)\end{array}$ & $\begin{array}{c}0.469^{a} \\
(5.590)\end{array}$ & $\begin{array}{c}0.365^{\mathrm{a}} \\
(3.150)\end{array}$ & $\begin{array}{c}0.321^{a} \\
(6.930)\end{array}$ \\
\hline
\end{tabular}

Second Stage: Public versus Private Private Private Private Equity Convertibles Debt (vs. Pu. Eq) (vs. Pu. Conv.) (vs. Pu. Debt)

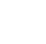


Table 6A

\section{Economic Significance - Security First Model}

This table illustrates the economic significance of our results. We compute the predicted probability for each deal in our dataset using the nested logit model of Table 4 . Then we vary each specific variable by $+/-1 / 2$ of its standard deviation, and evaluate the change in each predicted probability, keeping all other variables fixed. We then average the marginal effects over all firms in the sample. The last column is the sum of the absolute value of the marginal effects on each choice.

\begin{tabular}{lccccccc} 
& $\begin{array}{c}\text { Public } \\
\text { Debt }\end{array}$ & $\begin{array}{c}\text { Public } \\
\text { Convertibles }\end{array}$ & $\begin{array}{c}\text { Public } \\
\text { Equity }\end{array}$ & $\begin{array}{c}\text { Private } \\
\text { Debt }\end{array}$ & $\begin{array}{c}\text { Private } \\
\text { Convertibles }\end{array}$ & $\begin{array}{c}\text { Private } \\
\text { Equity }\end{array}$ & $\begin{array}{c}\text { Total } \\
\text { Variation }\end{array}$ \\
\hline Analyst Earnings Surprise & $-1.2 \%$ & $0.1 \%$ & $-7.0 \%$ & $5.6 \%$ & $1.2 \%$ & $1.4 \%$ & $16.4 \%$ \\
Cash Flow Volatility & $-4.0 \%$ & $1.2 \%$ & $2.2 \%$ & $-0.8 \%$ & $0.8 \%$ & $0.6 \%$ & $9.6 \%$ \\
R\&D / lagged PPE & $-6.7 \%$ & $2.1 \%$ & $2.6 \%$ & $1.4 \%$ & $0.0 \%$ & $0.5 \%$ & $13.4 \%$ \\
Tobin's $q$ & $-8.8 \%$ & $2.1 \%$ & $3.4 \%$ & $0.1 \%$ & $1.4 \%$ & $1.7 \%$ & $17.6 \%$ \\
Profitability & $4.4 \%$ & $-2.7 \%$ & $-2.1 \%$ & $4.8 \%$ & $-1.7 \%$ & $-2.7 \%$ & $18.3 \%$ \\
Financial Distress & $4.7 \%$ & $0.7 \%$ & $-0.3 \%$ & $-7.4 \%$ & $1.7 \%$ & $0.5 \%$ & $15.2 \%$ \\
Corporate Governance & $-0.5 \%$ & $0.3 \%$ & $-0.4 \%$ & $0.0 \%$ & $0.1 \%$ & $0.6 \%$ & $1.9 \%$ \\
Log Size & $18.6 \%$ & $4.2 \%$ & $-3.6 \%$ & $-9.9 \%$ & $-4.4 \%$ & $-5.0 \%$ & $45.7 \%$ \\
Predicted Financial Need & $-0.4 \%$ & $1.5 \%$ & $3.2 \%$ & $0.2 \%$ & $-1.2 \%$ & $-3.3 \%$ & $9.8 \%$ \\
Debt/Asset Ratio & $0.3 \%$ & $-0.2 \%$ & $1.2 \%$ & $-1.8 \%$ & $0.5 \%$ & $0.0 \%$ & $4.1 \%$ \\
Marginal Tax Rate & $0.3 \%$ & $-0.7 \%$ & $0.7 \%$ & $1.9 \%$ & $-0.9 \%$ & $-1.3 \%$ & $5.8 \%$ \\
Cumulative Abnormal Stock Return & $1.9 \%$ & $2.3 \%$ & $4.4 \%$ & $-8.0 \%$ & $-0.9 \%$ & $0.4 \%$ & $17.8 \%$ \\
Cumulative Market Return & $0.4 \%$ & $0.3 \%$ & $1.1 \%$ & $-1.7 \%$ & $-0.6 \%$ & $0.5 \%$ & $4.7 \%$ \\
Aaa Bond Rate & $-3.4 \%$ & $-2.3 \%$ & $1.1 \%$ & $3.1 \%$ & $0.9 \%$ & $0.7 \%$ & $11.5 \%$ \\
Credit Spread: Baa - Aaa & $-4.3 \%$ & $-0.7 \%$ & $0.5 \%$ & $2.3 \%$ & $-0.2 \%$ & $2.4 \%$ & $10.3 \%$ \\
\hline
\end{tabular}


Table 6B: Goodness of Fit

Predicted versus Actual Choices

For each choice made by firms, this table shows the predicted choices made using the model and coefficients of Table 5. The predicted choice is the maximum probability over the six possible choices in Table 5. For each type of security issued, the first row gives the number predicted to choose the security given in the column header. The second row gives the percentage predicted to choose that security versus the actual choice. The third row gives the percentage of observed, predicted pairs divided by the overall number predicted to issue that security.

\begin{tabular}{|c|c|c|c|c|c|c|c|}
\hline & \multicolumn{7}{|c|}{ Predicted Choice } \\
\hline $\begin{array}{l}\text { Observed } \\
\text { Choice }\end{array}$ & $\begin{array}{c}\text { Public } \\
\text { Debt }\end{array}$ & $\begin{array}{c}\text { Public } \\
\text { Convertibles }\end{array}$ & $\begin{array}{l}\text { Public } \\
\text { Equity }\end{array}$ & $\begin{array}{c}\text { Private } \\
\text { Debt }\end{array}$ & $\begin{array}{c}\text { Private } \\
\text { Convertibles }\end{array}$ & $\begin{array}{l}\text { Private } \\
\text { Equity }\end{array}$ & $\begin{array}{r}\text { Observed } \\
\text { Count }\end{array}$ \\
\hline Public Debt & $\begin{array}{c}1,381 \\
61 \% \\
62 \%\end{array}$ & $\begin{array}{c}14 \\
1 \% \\
13 \%\end{array}$ & $\begin{array}{l}25 \\
1 \% \\
6 \%\end{array}$ & $\begin{array}{c}843 \\
37 \% \\
18 \%\end{array}$ & $\begin{array}{c}2 \\
0 \% \\
1 \%\end{array}$ & $\begin{array}{c}1 \\
0 \% \\
0 \%\end{array}$ & 2,266 \\
\hline Public Convertibles & $\begin{array}{c}154 \\
26 \% \\
7 \%\end{array}$ & $\begin{array}{c}38 \\
7 \% \\
34 \%\end{array}$ & $\begin{array}{c}69 \\
12 \% \\
16 \%\end{array}$ & $\begin{array}{c}306 \\
52 \% \\
7 \%\end{array}$ & $\begin{array}{c}0 \\
0 \% \\
0 \%\end{array}$ & $\begin{array}{c}16 \\
3 \% \\
2 \%\end{array}$ & 583 \\
\hline Public Equity & $\begin{array}{c}83 \\
9 \% \\
4 \%\end{array}$ & $\begin{array}{c}23 \\
2 \% \\
21 \%\end{array}$ & $\begin{array}{l}211 \\
23 \% \\
48 \%\end{array}$ & $\begin{array}{l}528 \\
57 \% \\
11 \%\end{array}$ & $\begin{array}{c}8 \\
1 \% \\
3 \%\end{array}$ & $\begin{array}{c}75 \\
8 \% \\
11 \%\end{array}$ & 928 \\
\hline Private Debt & $\begin{array}{l}591 \\
17 \% \\
26 \%\end{array}$ & $\begin{array}{c}22 \\
1 \% \\
20 \%\end{array}$ & $\begin{array}{c}72 \\
2 \% \\
16 \%\end{array}$ & $\begin{array}{c}2,624 \\
78 \% \\
57 \%\end{array}$ & $\begin{array}{c}32 \\
1 \% \\
13 \%\end{array}$ & $\begin{array}{l}41 \\
1 \% \\
6 \%\end{array}$ & 3,382 \\
\hline Private Convertibles & $\begin{array}{c}12 \\
2 \% \\
1 \%\end{array}$ & $\begin{array}{c}5 \\
1 \% \\
5 \%\end{array}$ & $\begin{array}{l}24 \\
5 \% \\
5 \%\end{array}$ & $\begin{array}{c}172 \\
33 \% \\
4 \%\end{array}$ & $\begin{array}{c}124 \\
24 \% \\
50 \%\end{array}$ & $\begin{array}{c}181 \\
35 \% \\
27 \%\end{array}$ & 518 \\
\hline Private Equity & $\begin{array}{c}18 \\
3 \% \\
1 \%\end{array}$ & $\begin{array}{c}9 \\
1 \% \\
8 \%\end{array}$ & $\begin{array}{l}39 \\
6 \% \\
9 \%\end{array}$ & $\begin{array}{c}165 \\
25 \% \\
4 \%\end{array}$ & $\begin{array}{c}82 \\
12 \% \\
33 \%\end{array}$ & $\begin{array}{l}356 \\
53 \% \\
53 \%\end{array}$ & 669 \\
\hline Predicted Count & 2,239 & 111 & 440 & 4,638 & 248 & 670 & 8,346 \\
\hline & Predic & ed Market & & Observed & & Predicted Sec & curity \\
\hline Observed Market & Public & Private & & Security & Debt & Convertibles & Equity \\
\hline Public & $\begin{array}{l}1,998 \\
72 \%\end{array}$ & $\begin{array}{l}1,779 \\
32 \%\end{array}$ & & Debt & $\begin{array}{r}5,439 \\
79 \%\end{array}$ & $\begin{array}{r}70 \\
19 \%\end{array}$ & $\begin{array}{r}139 \\
13 \%\end{array}$ \\
\hline Private & $\begin{array}{l}792 \\
17 \% \\
28 \%\end{array}$ & $\begin{array}{c}3,777 \\
83 \% \\
68 \%\end{array}$ & & Convertible & $\begin{array}{r}644 \\
58 \% \\
9 \%\end{array}$ & $\begin{array}{r}167 \\
15 \% \\
47 \%\end{array}$ & $\begin{array}{r}290 \\
26 \% \\
26 \%\end{array}$ \\
\hline & & & & Equity & $\begin{array}{r}794 \\
50 \% \\
12 \%\end{array}$ & $\begin{array}{r}122 \\
8 \% \\
34 \%\end{array}$ & $\begin{array}{r}681 \\
43 \% \\
61 \%\end{array}$ \\
\hline
\end{tabular}


Table 7

Security Type and Pecking Order Tests

Table presents coefficient estimates from a nested logit regression testing the impact of asymmetric information and risk on firm public and private security choice by public firms. First stage is the decision of market with coefficients representing tendency relative to the public market. Second stage is the choice of security conditional on market, with coefficients representing tendency versus debt issuance. All firm-specific variables are lagged. Explanatory variables are as defined in Table 2A and they have all been normalized by their standard deviation (except the dummy variable financial distress). Analyst earnings surprise is the absolute value of actual earnings less median analyst forecast divided the price per share. (Robust Z-statistics are presented in parentheses.) Predicted financial need (internal funding deficit) is the instrumented amount of capital expenditures plus increase in net working capital less operating income before depreciation. Chi-squared statistic for test of overall significance is 11693 ( $p$-value .001). Sample is 8346 security issues. Industry fixed effects are included for each security type.

\section{Explanatory Variables}

Asymmetric Information Measure

Analyst Earnings Surprise

Risk Measure

Cash Flow Volatility

$\underline{\text { Investment Opportunities }}$

R\&D / lagged PPE

Tobin's $q$

Profitability

(Operating cash flow/ lagged assets)

Financial Distress

(Z-score<1.81)

Size Measures

Log Size

(Firm Value)

Predicted Financial Need

Debt and Taxes

Debt/Asset Ratio

(Industry Adjusted)

Marginal Tax Rate

Market Timing \& Market Characteristics

Cumulative Abnormal Stock Return

(250 prior days)

Cumulative Market Return

(Prior year)

Aaa Bond Rate

Credit Spread: Baa - Aaa
Corporate Governance

\section{\begin{tabular}{r|r} 
First Stage & Second Stage \\
Market Decision & Security Decision
\end{tabular}}

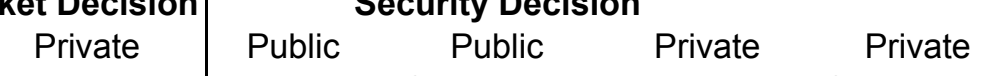
(vs. Public Equity Convertibles Equity Convertibles \begin{tabular}{c|cc} 
Market) & (vs. Public Debt) (vs. Private Debt) \\
\hline $0.215^{\circ}$ & $-0.773^{\circ}$ & $0.0262^{\circ}$
\end{tabular}

\begin{tabular}{c|cccc}
$0.215^{\mathrm{a}}$ & $-0.773^{\mathrm{a}}$ & -0.026 & $0.082^{\mathrm{c}}$ & $0.118^{\mathrm{a}}$ \\
$(3.480)$ & $(-4.730)$ & $(-.280)$ & $(1.940)$ & $(2.880)$ \\
& & & & \\
$0.206^{\mathrm{c}}$ & $0.538^{\mathrm{a}}$ & $0.441^{\mathrm{a}}$ & $0.308^{\mathrm{a}}$ & $0.334^{\mathrm{a}}$ \\
$(1.730)$ & $(4.600)$ & $(3.530)$ & $(4.300)$ & $(4.590)$
\end{tabular}

$(1.730)$

$(4.600)$

\begin{tabular}{c|cccc}
$0.360^{\mathrm{b}}$ & $0.725^{\mathrm{a}}$ & $0.736^{\mathrm{a}}$ & $0.230^{\mathrm{a}}$ & $0.141^{\mathrm{b}}$ \\
$(2.070)$ & $(4.630)$ & $(4.640)$ & $(3.590)$ & $(2.060)$
\end{tabular}

\begin{tabular}{c|cccc}
$0.491^{\mathrm{a}}$ & $0.997^{\mathrm{a}}$ & $0.875^{\mathrm{a}}$ & $0.656^{\mathrm{a}}$ & $0.634^{\mathrm{a}}$ \\
$(4.690)$ & $(11.690)$ & $(10.190)$ & $(9.650)$ & $(8.970)$ \\
-0.145 & $-0.632^{\mathrm{a}}$ & $-0.769^{\mathrm{a}}$ & $-0.958^{\mathrm{a}}$ & $-0.827^{\mathrm{a}}$ \\
$(-1.490)$ & $(-6.300)$ & $(-7.320)$ & $(-11.770)$ & $(-9.930)$
\end{tabular}

\begin{tabular}{r|rrcr}
$-0.431^{\mathrm{a}}$ & -0.222 & -0.083 & $0.413^{\mathrm{a}}$ & $0.563^{\mathrm{a}}$ \\
$(-4.250)$ & $(-1.440)$ & $(-.520)$ & $(2.560)$ & $(3.430)$ \\
0.030 & 0.007 & 0.067 & $0.143^{\mathrm{a}}$ & 0.082 \\
$(.910)$ & $(.140)$ & $(1.300)$ & $(2.560)$ & $(1.390)$
\end{tabular}

\begin{tabular}{c|cccc}
$-1.397^{\mathrm{a}}$ & $-1.778^{\mathrm{a}}$ & $-0.497^{\mathrm{a}}$ & $-1.402^{\mathrm{a}}$ & $-1.4899^{\mathrm{a}}$ \\
$(-14.750)$ & $(-20.300)$ & $(-6.590)$ & $(-13.430)$ & $(-13.530)$
\end{tabular}

\begin{tabular}{l|lccr}
0.003 & $0.234^{\mathrm{b}}$ & $0.184^{\mathrm{a}}$ & $-0.800^{\mathrm{a}}$ & -0.436 \\
$(.050)$ & $(2.390)$ & $(3.820)$ & $(-5.130)$ & $(-1.480)$
\end{tabular}

\begin{tabular}{r|cccc} 
& & $(2.390)$ & $(-820)$ & $(-1.480)$ \\
-0.052 & $0.134^{\mathrm{a}}$ & -0.014 & $0.113^{\mathrm{c}}$ & $0.179^{\mathrm{a}}$ \\
$(-1.470)$ & $(2.680)$ & $(-.270)$ & $(1.940)$ & $(2.970)$ \\
0.023 & 0.001 & $-0.14)^{\mathrm{b}}$ & $-0.434^{\mathrm{a}}$ & $-0.381^{\mathrm{a}}$ \\
$(.660)$ & $(.020)$ & $(-2.430)$ & $(-5.360)$ & $(-4.640)$
\end{tabular}

\begin{tabular}{|c|c|c|c|c|}
\hline $\begin{array}{c}-0.333^{a} \\
(-5.930)\end{array}$ & $\begin{array}{c}0.387^{a} \\
(6.720)\end{array}$ & $\begin{array}{c}0.328^{a} \\
(5.450)\end{array}$ & $\begin{array}{c}0.305^{a} \\
(5.200)\end{array}$ & $\begin{array}{l}0.041 \\
(.580)\end{array}$ \\
\hline $\begin{array}{l}-0.073^{c} \\
(-1.950)\end{array}$ & $\begin{array}{c}0.102^{c} \\
(1.940)\end{array}$ & $\begin{array}{l}0.028 \\
(.480)\end{array}$ & $\begin{array}{c}0.142^{a} \\
(2.520)\end{array}$ & $\begin{array}{l}-0.021 \\
(-.350)\end{array}$ \\
\hline $\begin{array}{c}0.298^{a} \\
(7.250)\end{array}$ & $\begin{array}{c}0.364^{a} \\
(5.970)\end{array}$ & $\begin{array}{l}-0.140^{b} \\
(-2.240)\end{array}$ & $\begin{array}{c}0.1744^{\mathrm{a}} \\
(2.560)\end{array}$ & $\begin{array}{c}0.227^{a} \\
(3.010)\end{array}$ \\
\hline $\begin{array}{c}0.318^{a} \\
(6.920)\end{array}$ & $\begin{array}{c}0.383^{a} \\
(5.590)\end{array}$ & $\begin{array}{c}0.169^{b} \\
(2.340)\end{array}$ & $\begin{array}{c}0.500^{\mathrm{a}} \\
(7.200)^{-}\end{array}$ & $\begin{array}{c}0.144^{\mathrm{c}} \\
(1.880)\end{array}$ \\
\hline
\end{tabular}

a,b,c - Significantly different from zero at the one-percent (five, ten) level of significance. 
Table 8

\section{Economic Significance: Security Type}

This table illustrates the economic significance of our results. We compute the predicted probability for each deal in our dataset using the nested logit model of Table 6 . Then we vary each specific variable by $+/-1 / 2$ of its standard deviation, and evaluate the change in each predicted probability, keeping all other variables fixed. We then average the marginal effects over all firms in the sample. The last column is the sum of the absolute value of the marginal effects on each choice.

\begin{tabular}{lccccccc} 
& $\begin{array}{c}\text { Public } \\
\text { Debt }\end{array}$ & $\begin{array}{c}\text { Public } \\
\text { Convertibles }\end{array}$ & $\begin{array}{c}\text { Public } \\
\text { Equity }\end{array}$ & $\begin{array}{c}\text { Private } \\
\text { Debt }\end{array}$ & $\begin{array}{c}\text { Private } \\
\text { Convertibles }\end{array}$ & $\begin{array}{c}\text { Private } \\
\text { Equity }\end{array}$ & $\begin{array}{c}\text { Total } \\
\text { Variation }\end{array}$ \\
\hline Analyst Earnings Surprise & $-0.9 \%$ & $0.0 \%$ & $-7.8 \%$ & $6.5 \%$ & $1.1 \%$ & $1.2 \%$ & $17.5 \%$ \\
Cash Flow Volatility & $-4.0 \%$ & $1.2 \%$ & $2.3 \%$ & $-0.8 \%$ & $0.7 \%$ & $0.6 \%$ & $9.6 \%$ \\
R\&D / lagged PPE & $-6.4 \%$ & $2.3 \%$ & $2.8 \%$ & $0.7 \%$ & $0.0 \%$ & $0.5 \%$ & $12.7 \%$ \\
Tobin's $q$ & $-8.6 \%$ & $2.2 \%$ & $3.4 \%$ & $0.0 \%$ & $1.4 \%$ & $1.7 \%$ & $17.2 \%$ \\
Profitability & $4.4 \%$ & $-2.8 \%$ & $-2.1 \%$ & $4.7 \%$ & $-1.6 \%$ & $-2.7 \%$ & $18.3 \%$ \\
Financial Distress & $4.7 \%$ & $0.7 \%$ & $-0.1 \%$ & $-7.5 \%$ & $1.5 \%$ & $0.6 \%$ & $15.1 \%$ \\
Corporate Governance & $-0.5 \%$ & $0.2 \%$ & $-0.4 \%$ & $0.0 \%$ & $0.1 \%$ & $0.6 \%$ & $1.8 \%$ \\
Log Size & $18.6 \%$ & $4.2 \%$ & $-3.6 \%$ & $-9.8 \%$ & $-4.6 \%$ & $-4.9 \%$ & $45.6 \%$ \\
Predicted Financial Need & $-0.4 \%$ & $1.3 \%$ & $2.8 \%$ & $0.6 \%$ & $-0.7 \%$ & $-3.5 \%$ & $9.2 \%$ \\
Debt/Asset Ratio & $0.3 \%$ & $-0.2 \%$ & $1.2 \%$ & $-1.8 \%$ & $0.5 \%$ & $0.0 \%$ & $4.0 \%$ \\
Marginal Tax Rate & $0.2 \%$ & $-0.6 \%$ & $0.7 \%$ & $2.0 \%$ & $-0.9 \%$ & $-1.4 \%$ & $5.8 \%$ \\
Cumulative Abnormal Stock Return & $2.1 \%$ & $2.4 \%$ & $4.5 \%$ & $-8.3 \%$ & $-1.1 \%$ & $0.4 \%$ & $18.7 \%$ \\
Cumulative Market Return & $0.5 \%$ & $0.2 \%$ & $1.1 \%$ & $-1.9 \%$ & $-0.5 \%$ & $0.5 \%$ & $4.7 \%$ \\
Aaa Bond Rate & $-3.5 \%$ & $-2.3 \%$ & $1.1 \%$ & $3.1 \%$ & $0.9 \%$ & $0.7 \%$ & $11.5 \%$ \\
Credit Spread: Baa - Aaa & $-4.4 \%$ & $-0.6 \%$ & $0.6 \%$ & $2.3 \%$ & $-0.2 \%$ & $2.4 \%$ & $10.4 \%$ \\
\hline
\end{tabular}


Table 9

Public and Private Security Issuance including 144-A Issued Securities

Table presents coefficient estimates from a nested logit regression testing the impact of asymmetric information and agency costs on public and private security issues by public firms. First stage is the decision of security with coefficients representing tendency relative to debt. Second stage is the choice of market conditional on security type, with coefficients representing tendency versus public market issuance. All firm-specific variables are lagged. Explanatory variables (except predicted financial need) are as defined in Table 2A and they have all been normalized by their standard deviation (except the dummy variable financial distress). Predicted financial need (internal funding deficit) is the instrumented amount of capital expenditures plus increase in net working capital less operating income before depreciation. (Robust Z-statistics are presented in parentheses.) Chi-squared statistic for test of overall significance is 13926 ( $p$-value .001). Sample is 7536 security issues. Industry fixed effects are included for each security type.

\begin{tabular}{|c|c|c|c|c|c|c|c|}
\hline \multirow[b]{2}{*}{$\begin{array}{l}\text { Explanatory Variables } \\
\text { Measures of Asymmetric Information }\end{array}$} & \multicolumn{2}{|c|}{$\begin{array}{l}\text { First Stage } \\
\text { Security Decision }\end{array}$} & \multicolumn{3}{|c|}{$\begin{array}{c}\text { Second Stage } \\
\text { Market Decision (vs. Public Market) }\end{array}$} & \multirow[b]{2}{*}{$\begin{array}{l}\text { 144-A Convertibles } \\
\text { (vs Public Conv.) vs }\end{array}$} & \multirow[b]{2}{*}{$\begin{array}{l}\text { 144-A Debt } \\
\text { s. Public Debt) }\end{array}$} \\
\hline & $\begin{array}{l}\text { Equity } \\
\text { (vs. Debt) }\end{array}$ & $\begin{array}{l}\text { Convertibles } \\
\text { (vs. Debt) }\end{array}$ & $\begin{array}{r}\text { Private Equity } \\
\text { (vs Public Equity) }\end{array}$ & $\begin{array}{l}\text { Private Conv. } \\
\text { (vs Public Conv.) }\end{array}$ & $\begin{array}{r}\text { Private Debt } \\
\text { (vs. Public Debt) } \\
\end{array}$ & & \\
\hline Analyst Earnings Dispersion & $\begin{array}{l}-0.278^{a} \\
(-3.100)\end{array}$ & $\begin{array}{l}0.051 \\
(.680)\end{array}$ & $\begin{array}{l}0.568^{a} \\
(5.260)\end{array}$ & $\begin{array}{l}0.192^{c} \\
(1.750)\end{array}$ & $\begin{array}{l}0.009 \\
(.190)\end{array}$ & $\begin{array}{l}-0.102 \\
(-.890)\end{array}$ & $\begin{array}{l}-0.001 \\
(-.020)\end{array}$ \\
\hline \multicolumn{8}{|l|}{ Risk Measure } \\
\hline Cash Flow Volatility & $(4.520)^{\mathrm{a}}$ & ${ }^{1.127^{a}}$ & $\begin{array}{l}-0.015 \\
(-.320)\end{array}$ & $\begin{array}{l}0.186 \\
(.890)\end{array}$ & $\begin{array}{l}0.911^{\mathrm{a}} \\
(4.720)\end{array}$ & $\begin{array}{l}0.094 \\
(.460)\end{array}$ & $\begin{array}{l}0.926^{\mathrm{a}} \\
(4.300)\end{array}$ \\
\hline \multicolumn{8}{|l|}{ Investment Opportunities Measure } \\
\hline R\&D / lagged PPE & $\begin{array}{c}0.732^{\mathrm{a}} \\
(3.090)\end{array}$ & $\begin{array}{l}0.578^{b} \\
(2.230)\end{array}$ & $\begin{array}{l}-0.130^{b} \\
(-2.360)\end{array}$ & $\begin{array}{l}0.077 \\
(.400)\end{array}$ & $\begin{array}{l}0.426 \\
(1.950)\end{array}$ & $\begin{array}{r}0.247 \\
(1.330)\end{array}$ & $\begin{array}{l}-0.077 \\
(-.280)\end{array}$ \\
\hline Tobin's $q$ & ${ }^{1.314^{a}}$ & $(6.610)^{\mathrm{a}}$ & $\begin{array}{l}0.186^{\mathrm{a}} \\
(2.890)\end{array}$ & $\begin{array}{l}0.386^{a} \\
(3.040)\end{array}$ & $\begin{array}{l}0.847^{\mathrm{a}} \\
(8.730)\end{array}$ & $\begin{array}{l}0.177^{c} \\
(1.640)\end{array}$ & $\begin{array}{l}0.563^{a} \\
(4.440)\end{array}$ \\
\hline $\begin{array}{l}\text { Profitability } \\
\text { (Operating cash flow/ lagged assets) }\end{array}$ & $\begin{array}{l}-0.960^{a} \\
(-6.030)\end{array}$ & $\begin{array}{c}-0.987^{a} \\
(-5.390)\end{array}$ & $\begin{array}{l}-0.558^{a} \\
(-7.130)\end{array}$ & $\begin{array}{l}-0.423^{b} \\
(-2.290)\end{array}$ & $\begin{array}{l}-0.479^{a} \\
(-4.470)\end{array}$ & $\begin{array}{l}-0.147 \\
(-.870)\end{array}$ & $\begin{array}{l}-0.436^{a} \\
(-3.310)\end{array}$ \\
\hline $\begin{array}{l}\text { Financial Distress } \\
(Z \text {-score }<1.81)\end{array}$ & $\begin{array}{l}0.166 \\
(.930)\end{array}$ & $\begin{array}{c}0.487^{\mathrm{b}} \\
(2.090)\end{array}$ & $\begin{array}{r}0.395^{\mathrm{c}} \\
(1.790)\end{array}$ & $\begin{array}{l}0.300 \\
(.840)\end{array}$ & $\begin{array}{l}0.038 \\
(.290)\end{array}$ & $\begin{array}{l}-0.277 \\
(-.870)\end{array}$ & $\begin{array}{r}0.804^{a} \\
(5.150)\end{array}$ \\
\hline Corporate Governance & $\begin{array}{l}0.044 \\
(.800)\end{array}$ & $\begin{array}{l}0.050 \\
(.650)\end{array}$ & $\begin{array}{l}0.136^{\mathrm{c}} \\
(1.860)\end{array}$ & $\begin{array}{r}0.129 \\
(1.020)\end{array}$ & $\begin{array}{r}0.062 \\
(1.520)\end{array}$ & $\begin{array}{r}0.126 \\
(1.150)\end{array}$ & $\begin{array}{r}0.071 \\
(1.320)\end{array}$ \\
\hline \multicolumn{8}{|l|}{ Size Measures } \\
\hline $\begin{array}{l}\text { Log Size } \\
\text { (Firm Value) }\end{array}$ & $\begin{array}{l}-2.324^{a} \\
(-7.390)\end{array}$ & $\begin{array}{c}-0.916^{a} \\
(-3.570)\end{array}$ & $\begin{array}{l}-0.942^{a} \\
(-6.550)\end{array}$ & $\begin{array}{r}-3.042^{\mathrm{a}} \\
(-11.740)\end{array}$ & $\begin{array}{l}-1.876 \\
(-21.280)\end{array}$ & $\begin{array}{l}-0.586^{a} \\
(-3.710)\end{array}$ & $\begin{array}{l}-1.255^{a} \\
(-13.830)\end{array}$ \\
\hline Predicted Financial Need & $\begin{array}{r}0.187 \\
(1.430)\end{array}$ & $\begin{array}{c}0.207^{\mathrm{a}} \\
(3.310)\end{array}$ & $\begin{array}{l}-1.226^{a} \\
(-4.330)\end{array}$ & $\begin{array}{l}-0.843^{b} \\
(-2.350)\end{array}$ & $\begin{array}{r}-0.095 \\
(-1.410)\end{array}$ & $\begin{array}{r}-0.150 \\
(-1.300)\end{array}$ & $\begin{array}{l}0.028 \\
(.400)\end{array}$ \\
\hline \multicolumn{8}{|l|}{ Debt and Taxes } \\
\hline $\begin{array}{l}\text { Debt/Asset Ratio } \\
\text { (Industry Adjusted) }\end{array}$ & $\begin{array}{r}0.304^{\mathrm{a}} \\
(4.420)\end{array}$ & $\begin{array}{l}0.082 \\
(.940)\end{array}$ & $\begin{array}{l}-0.073 \\
(-.990)\end{array}$ & $\begin{array}{l}0.371^{\mathrm{a}} \\
(2.820)\end{array}$ & $\begin{array}{c}0.124^{\mathrm{a}} \\
(2.590)\end{array}$ & $\begin{array}{r}0.152 \\
(1.340)\end{array}$ & $\begin{array}{r}0.269^{a} \\
(4.510)\end{array}$ \\
\hline Marginal Tax Rate & $\begin{array}{l}-0.056 \\
(-.920)\end{array}$ & $\begin{array}{c}-0.144^{c} \\
(-1.710)\end{array}$ & $\begin{array}{l}-0.370^{a} \\
(-3.690)\end{array}$ & $\begin{array}{l}-0.308^{b} \\
(-2.070)\end{array}$ & $\begin{array}{l}-0.031 \\
(-.700)\end{array}$ & $\begin{array}{r}-0.140 \\
(-1.180)\end{array}$ & $\begin{array}{l}-0.175^{a} \\
(-3.020)\end{array}$ \\
\hline \multicolumn{8}{|l|}{ Market Timing \& Market Characteristics } \\
\hline $\begin{array}{l}\text { Cumulative Abnormal Stock Return } \\
\text { (250 prior days) }\end{array}$ & $\begin{array}{l}0.463^{\mathrm{a}} \\
(5.830)\end{array}$ & $\begin{array}{c}0.396^{\mathrm{a}} \\
(4.360)\end{array}$ & $\begin{array}{l}-0.450^{a} \\
(-7.000)\end{array}$ & $\begin{array}{l}-0.641^{\mathrm{a}} \\
(-5.470)\end{array}$ & $\begin{array}{l}-0.217^{\mathrm{a}} \\
(-2.990)\end{array}$ & $\begin{array}{l}-0.039 \\
(-.460)\end{array}$ & $\begin{array}{l}0.168^{b} \\
(1.970)\end{array}$ \\
\hline $\begin{array}{l}\text { Cumulative Market Return } \\
\text { (Prior year) }\end{array}$ & $\begin{array}{l}-0.061 \\
(-.900)\end{array}$ & $\begin{array}{l}-0.057 \\
(-.640)\end{array}$ & $\begin{array}{l}-0.067 \\
(-.880)\end{array}$ & $\begin{array}{r}-0.219 \\
(-1.560)\end{array}$ & $\begin{array}{l}-0.152^{a} \\
(-3.260)\end{array}$ & $\begin{array}{l}-0.026 \\
(-.220)\end{array}$ & $\begin{array}{l}-0.217^{a} \\
(-3.610)\end{array}$ \\
\hline Aaa Bond Rate & $\begin{array}{l}0.304^{\mathrm{a}} \\
(4.210)^{-}\end{array}$ & $\begin{array}{l}0.055 \\
(.540)\end{array}$ & $\begin{array}{r}0.122 \\
(1.350)\end{array}$ & $\begin{array}{l}0.588^{a} \\
(3.350)\end{array}$ & $\begin{array}{l}0.228^{\mathrm{a}} \\
(4.600)\end{array}$ & $\begin{array}{l}-0.389^{a} \\
(-2.820)\end{array}$ & $\begin{array}{l}-0.149^{b} \\
(-2.310)\end{array}$ \\
\hline Credit Spread: Baa - Aaa & $\begin{aligned} & 0.349^{a} \\
&(4.250)\end{aligned}$ & $\begin{array}{l}0.016 \\
(.140)\end{array}$ & $\begin{array}{l}0.459^{a} \\
(4.970) \\
\end{array}$ & $\begin{aligned} & 0.590^{\mathrm{a}} \\
&(3.220)\end{aligned}$ & $\begin{array}{l}0.269^{a} \\
(4.790) \\
\end{array}$ & $\begin{array}{l}0.273^{\mathrm{c}} \\
(1.720)\end{array}$ & $\begin{array}{l}-0.057 \\
(-.750)\end{array}$ \\
\hline
\end{tabular}

a,b,c - Significantly different from zero at the one-percent (five, ten) level of significance. 


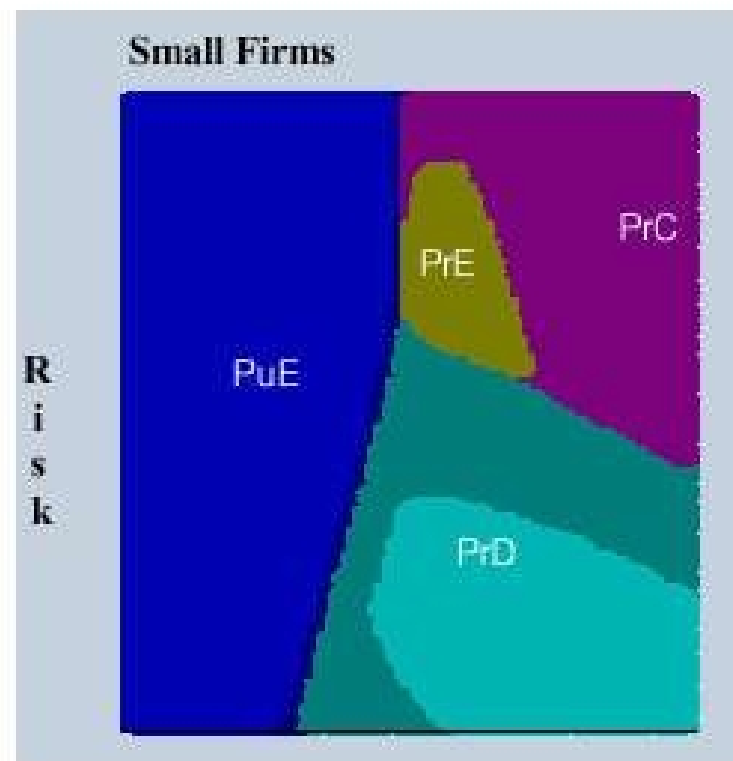

Earnings Surprise

\section{Medium Size Firms}

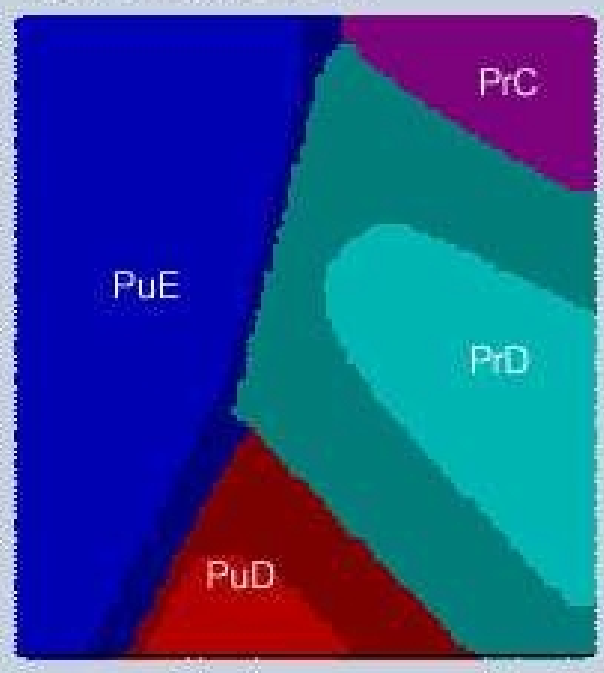

Earnings Surprise

\section{Large Firms}

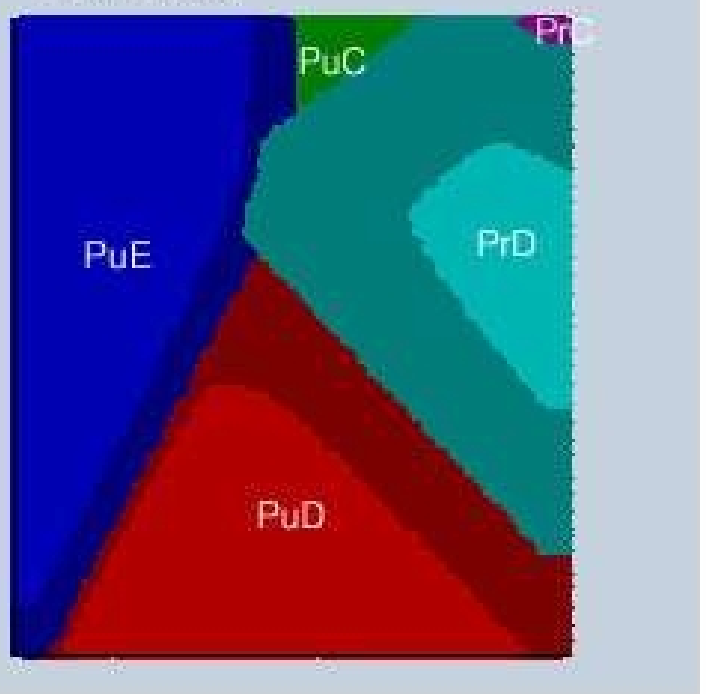

Earnings Surprise

Figure 1. Predicted Security-Market Choices by Size Groups. The figure shows the security with the maximum predicted probability of issuance using the coefficients of Table 5 as we vary risk and earnings surprise for three size groups: small-below $33^{\text {rd }}$ percentile, medium-between $33^{\text {rd }}$ and $66^{\text {th }}$-percentile, and large-above $66^{\text {th }}$ percentile. Risk (volatility of cash flows) is on the $y$-axis and asymmetric information (earnings surprise relative to analyst forecasts) is on the $\mathrm{x}$-axis. We hold all data at security means for the respective size group and then vary risk and asymmetric information proxies from $+/-10$ standard deviations away from the mean value for each size group. $\mathrm{PuE}(\mathrm{PrE})$ is public (private) equity, $\mathrm{PuC}(\mathrm{PrC})$ is public (private) convertibles, $\mathrm{PuD}(\mathrm{PrD})$ is public (private) Debt. Dark and light shading within regions represents predicted probability of that security greater than $50 \%$ and $0-50 \%$ higher than the next highest security. 


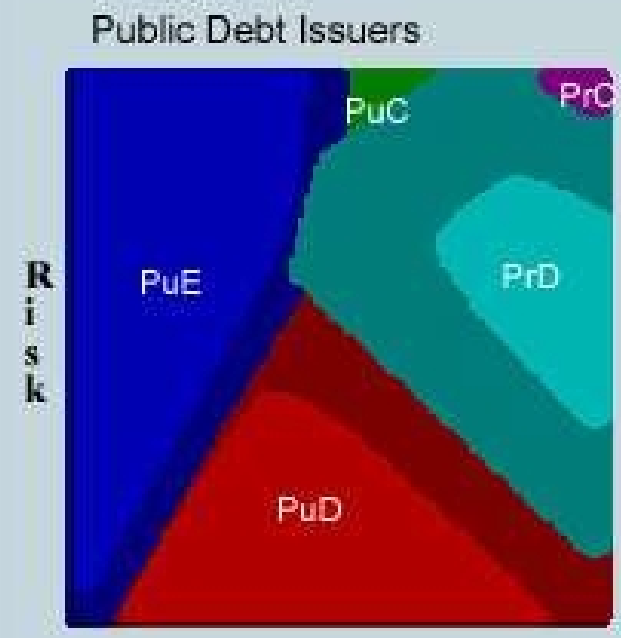

\section{Public Conv. Issuers}

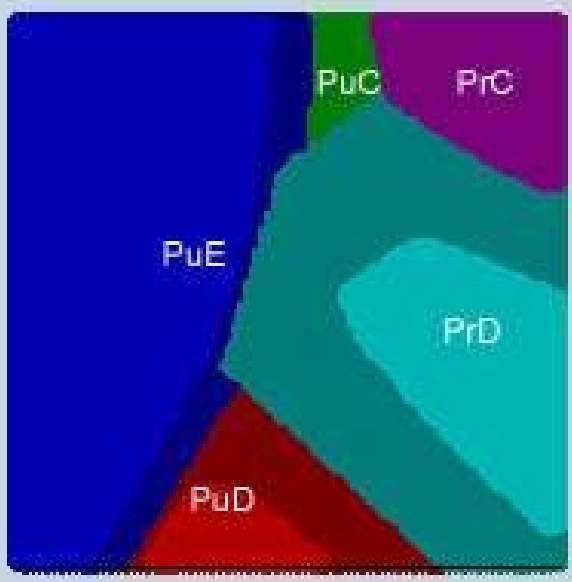

Private Debt Issuers

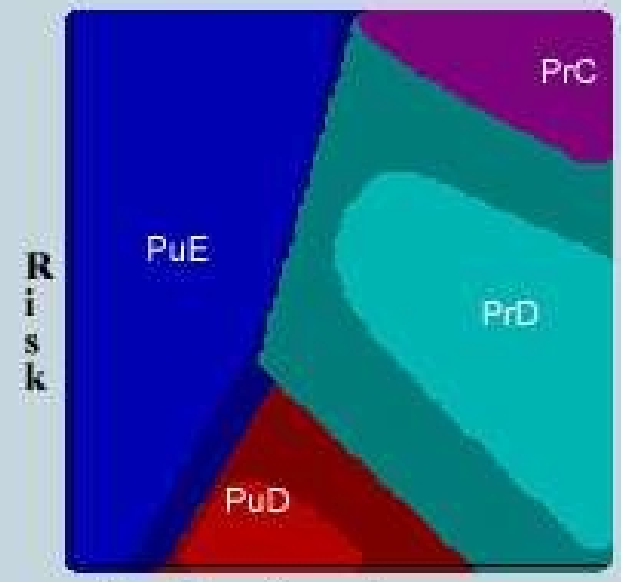

Earnings Surprise
Private Conv, Issuers

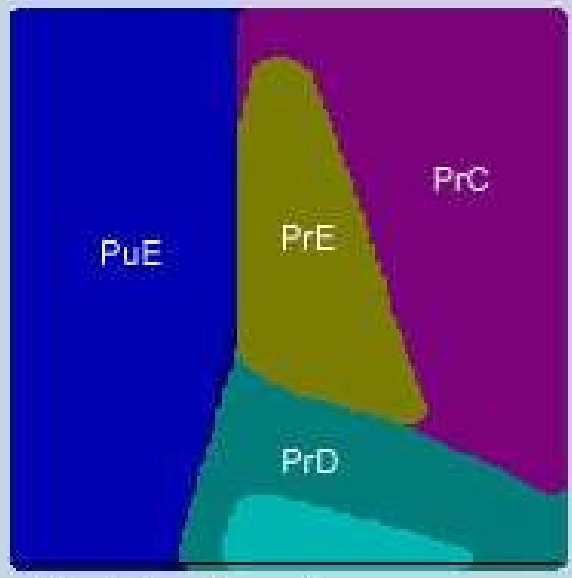

Earnings Surprise

\section{Public Equity Issuers}

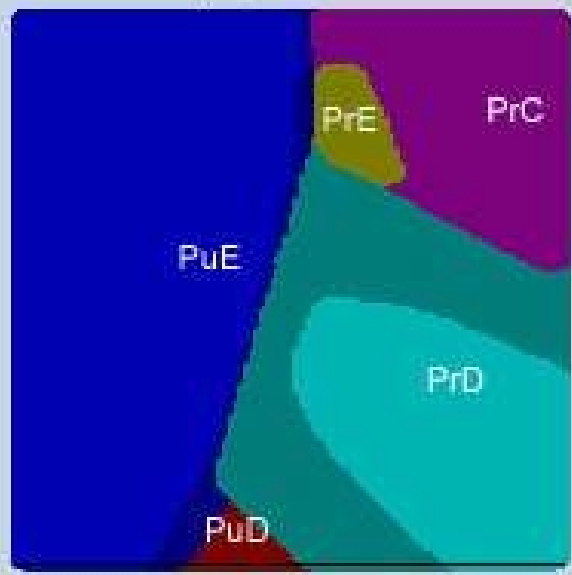

Private Equity Issuers

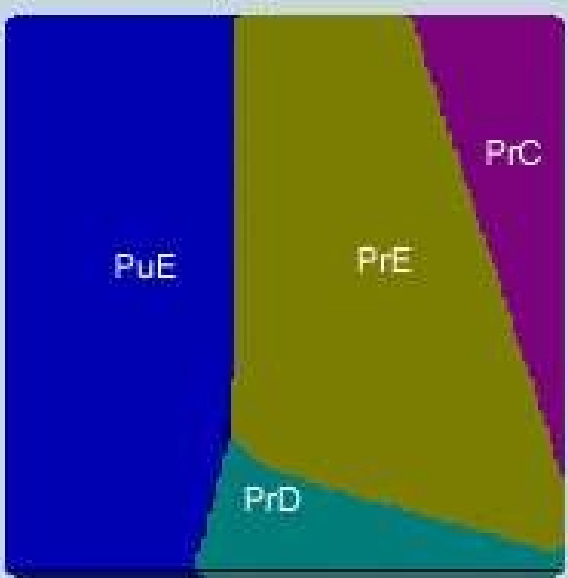

Earnings Surprise

Figure 2. Predicted Security-Market Choices: The figure shows the security with the maximum predicted probability of issuance using the coefficient estimates from Table 5 as we vary risk and asymmetric information (earnings surprise) for each of the six actual security choices. Risk (volatility of cash flows) is on the y-axis and asymmetric information (earnings surprise relative to analyst forecasts) is on the $\mathrm{x}$-axis. We hold all data at security means and then vary risk and asymmetric information proxies from $+/-10$ standard deviations away from the mean value for each security type. PuE (PrE) is public (private) equity, $\mathrm{PuC}(\mathrm{PrC})$ is public (private) convertibles, $\mathrm{PuD}(\mathrm{PrD})$ is public (private) Debt. Dark and light shading within regions represents predicted probability of that security greater than $50 \%$ and $0-50 \%$ higher than the next highest security. 